مقايسه و ارزيابى بيست روش تخمين تبخير - تعرق گياه مرجع مبتنى بر سه دسته كلى دماى هوا، تابش خورشيد و انتقال جرم در حوضه آبريز درياجه اروميه

اميد باباميرى ا* و يعقوب دين يزوهُ

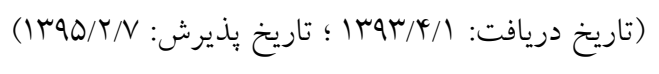

جكيده

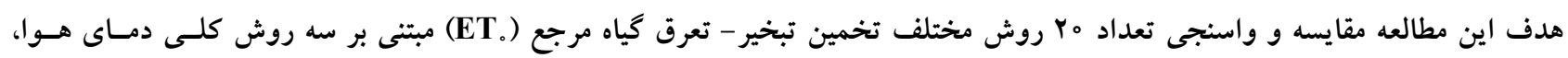

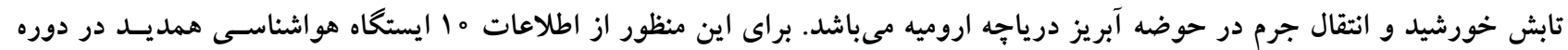

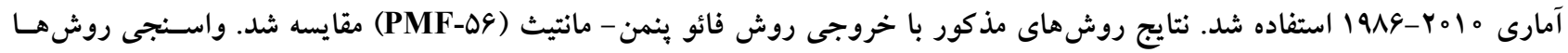

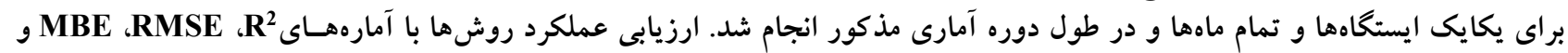

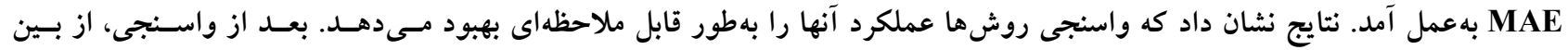

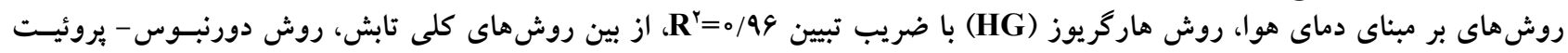

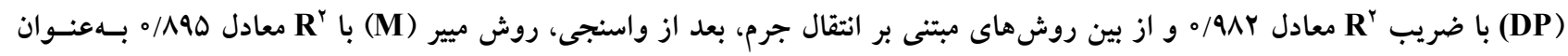

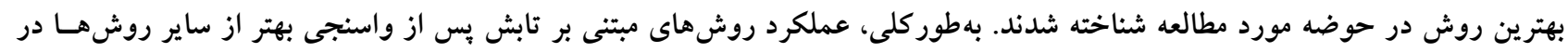

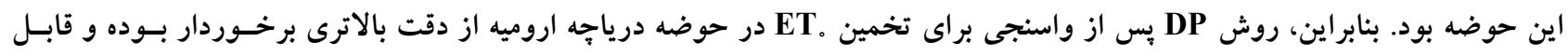
توصيه مىباشد.

وازههاى كليدى: تبخير - تعرق گياه مرجع، روش بنمن - مانتي، دماى هوا، انتقال جرم، تابش خورشيد

1. كروه مهندسى منابع آب، دانشكده كشاورزى، دانشخاه بوعلىسينا، همدان

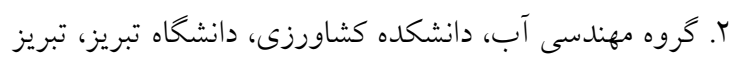

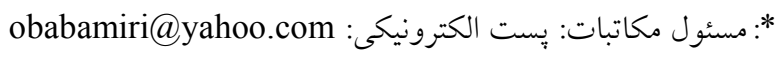


تخمين تبخير - تعـرق كيـاه مرجـع بـا نتـايج حاصـل از مــدل

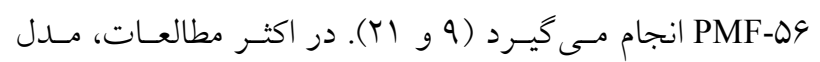

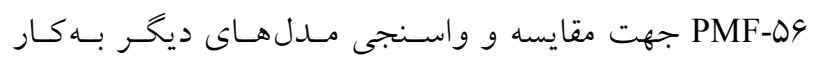

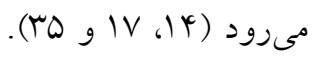

ET. مطالعات متعددى در زمينه واسنجى مدلهاى مختلـف

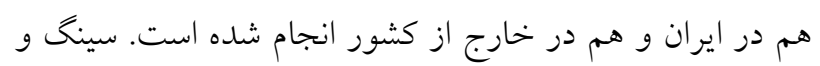

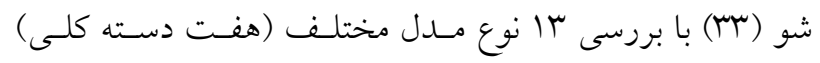
تبخير از سطح آزاد آب (بر مبناى انتقال جرم) در مقياس ماهانه،

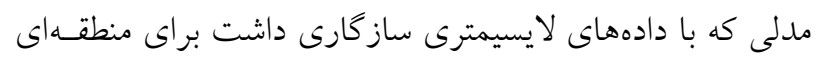

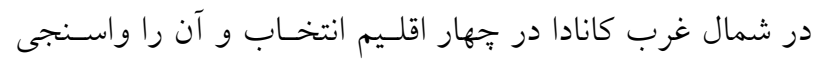
كردند. شو و سينگ (أl) هشت روش تخمسين تبخيـر - تعرق

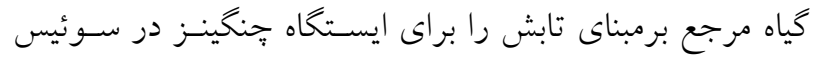

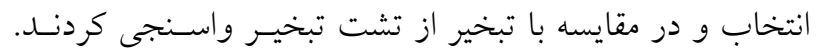

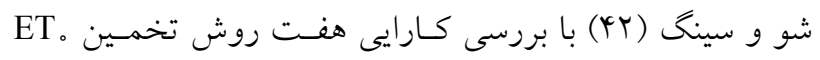

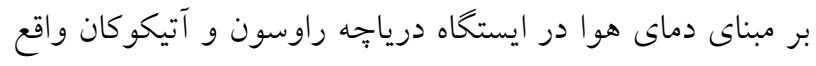

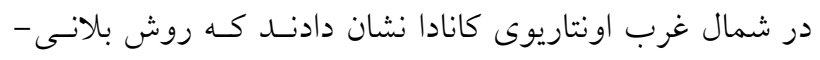

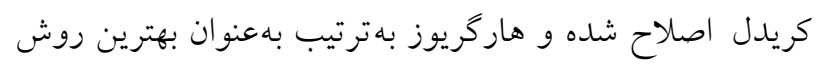

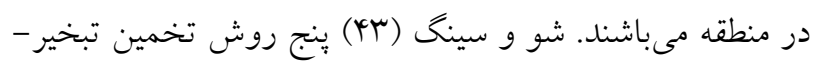
تعرق كياه مرجع را از بين سه روش كلى شامل بِنمن، (بر مبناى

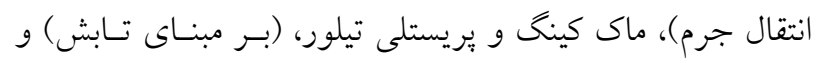

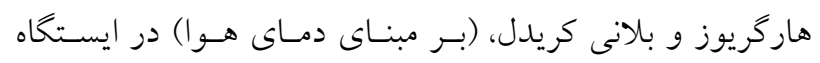

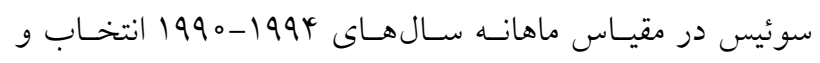

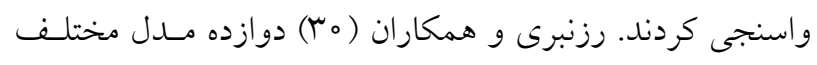

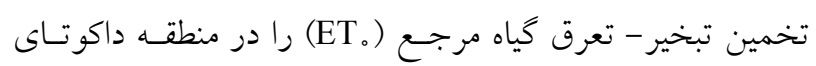

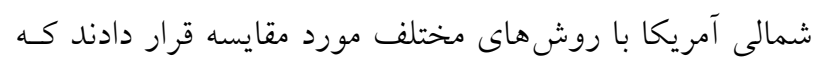

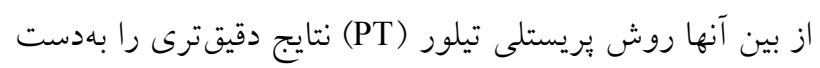

ترج كوويج و كولاكويج (广N) روشهـاى مختلـف تبخيـر -

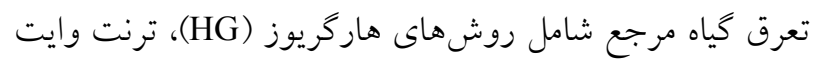
Jensen-) تورى Thornthwaite(TW)

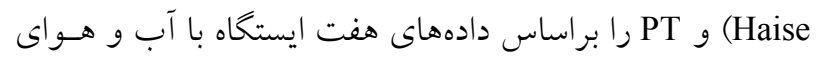
مرطوب در مقابل روش PMF-ه9 مقايسه و ارزيابى كردند. زاى

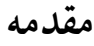

تبخير - تعرق كياه مرجع Evapotranspiration (ET。 يكسى از

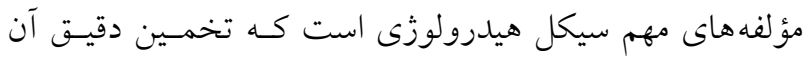

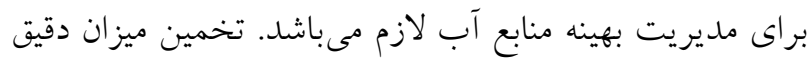

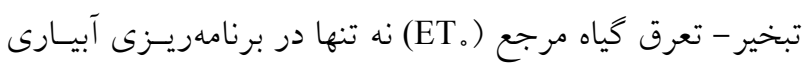

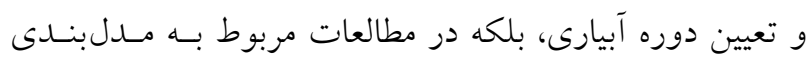

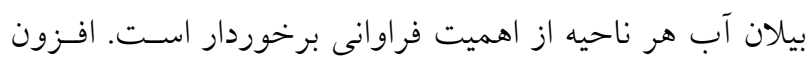

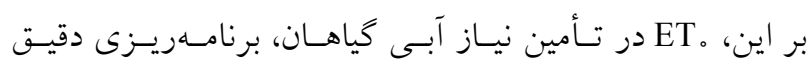

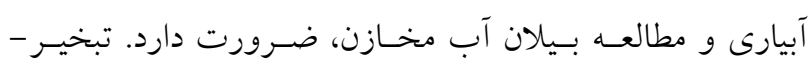

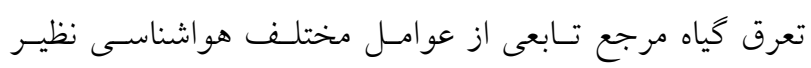

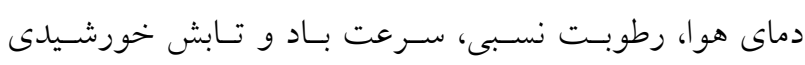

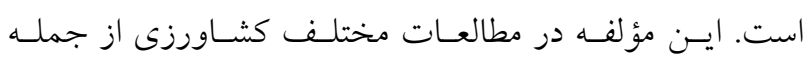

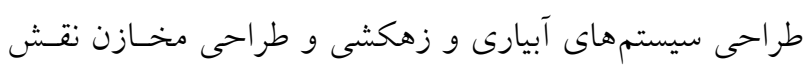

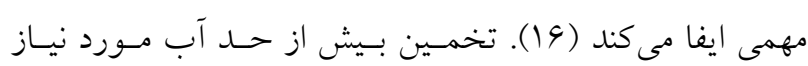

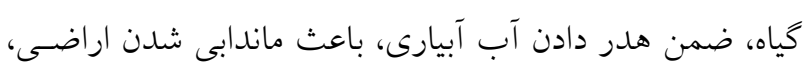

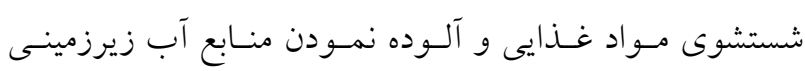

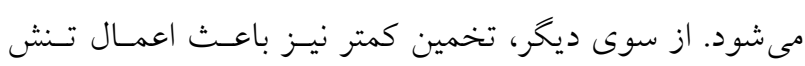

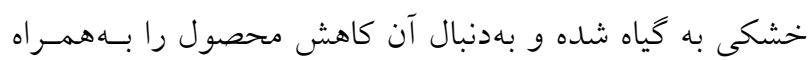
خواهد داشت (Yo) (Y).

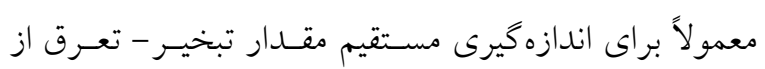

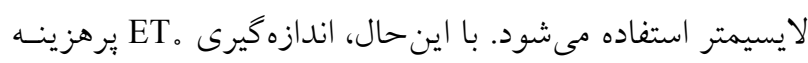
بوده و نيازمند صرف وقت زياد است كـه هميشـه امكـان يـذير

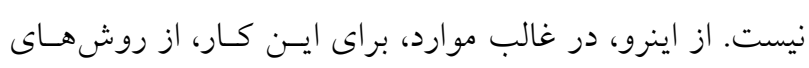

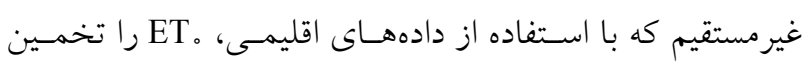

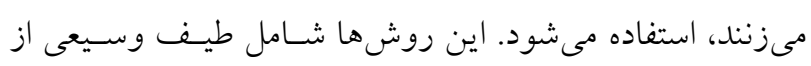

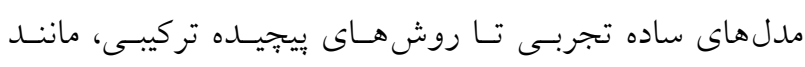

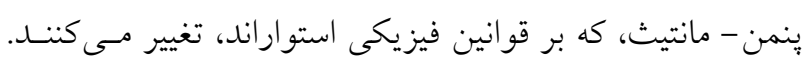

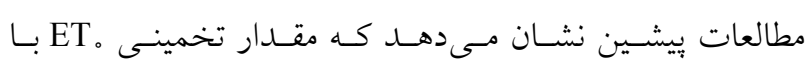

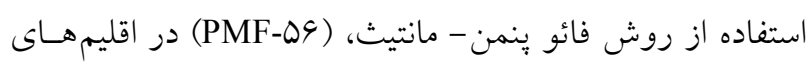

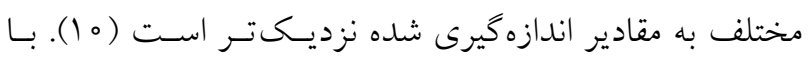
توجه به اين كه مقادير ET حاصل از لايسيمتر در اكثـر مـوارد

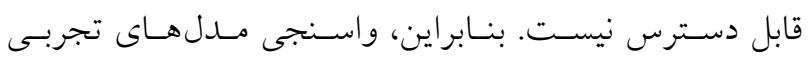


تعرق گياه مرجع بسط داده شده بر مبنـاى دمـاى هـوا، تـابش و

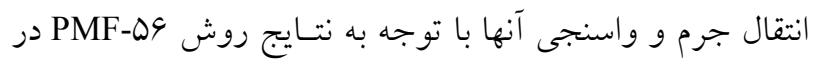
حوضه آبريز درياجه اروميه است.

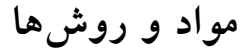
منطقه مورد مطالعه حوضـهـ آبريـز درياجــه اروميـه اسـت. ايـن

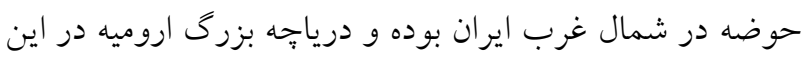
حوضه واقع شده است. اين حوضه به لحساظ جغرافيسيى مـابين

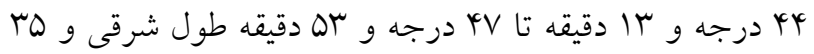

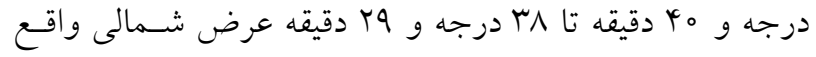
شده اسـت. مسـاحت حوضـه درياجـــ اروميـه حسدود كيلومترمربع است كه حدود ب/r\%٪ مساحت كل كشـور را در بـر

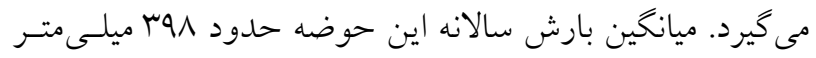
است. دادههاى مـورد اسـتفاده در ايـن تحقيـق شـامل ميـانخين، حداقل و حلداكثر دمـاى هـوا، ميـانخين رطوبـت نسـبى، تعـداد ساعات آفتابى و سرعت باد در مقياس ماهانه مىباشد. دادهها از

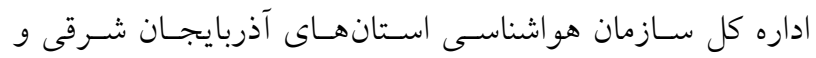
آذربايجان غربى اخذ شــند. تعـداد كمسى از دادهــاى مـذكور ناقص بودند كه با روشهاى مناسب بازسازى و قبل از استفاده

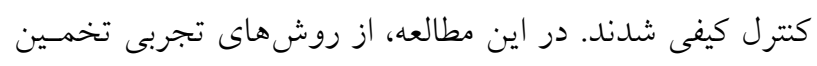

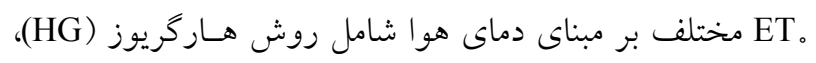

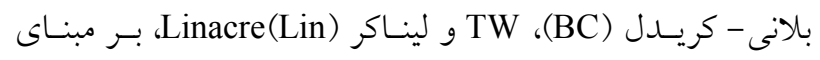

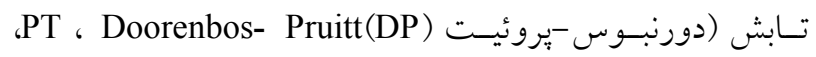

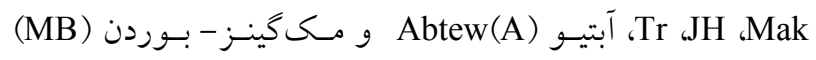
McGuinness -Bordne

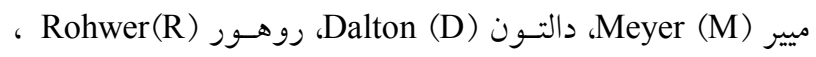

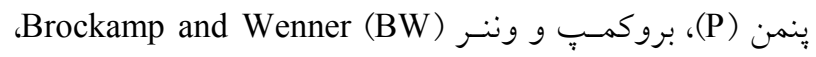

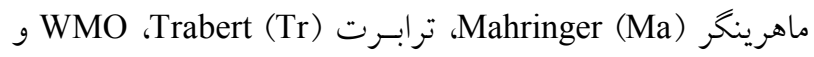
آلبرجت (Albrecht (Al) كه به دادههـاى ورودى كمتـرى نيـاز دارند، استفاده شد. در اين مطالعه، تعداد V ايستخاه هواشناسى در داخل حوضه و سه ايستكاه در حاشيه بيرونى حوضه (بهدليل

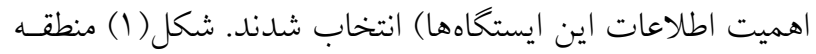

و همكاران (Y (F) نتايج تخمين تبخير - تعرق گياه مرجع حاصل

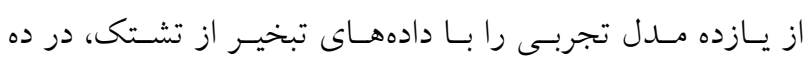
ايستخاه هواشناسى واقع در استان كانسو در شمال جين، مقايسه

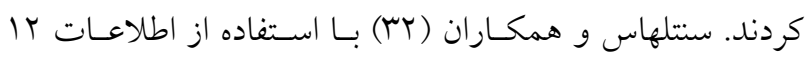
ايستخاه هو اشناسى واقع در جنوب كانادا مــدلهـاى هـاركريوز،

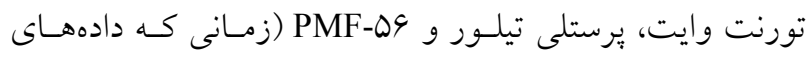
تابش و سرعت باد در دسترس نباشد) را براسـاس نتسايج مـدل

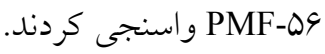

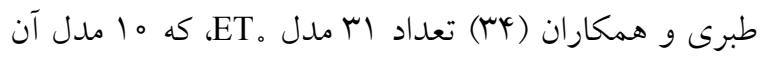

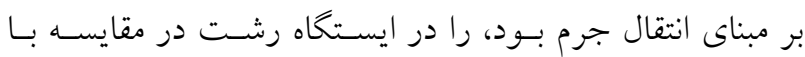
روش PMF-OS مقايسه كردند. جهانبخش اصل و همكـاران (1)

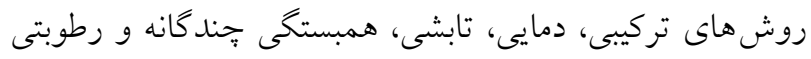

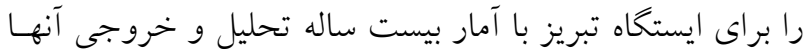
را با روش تشتك تبخير مقايسه كردند. شريفيان و همكاران (Y)

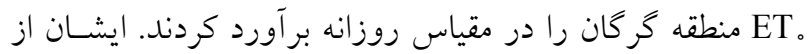

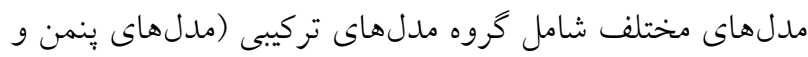

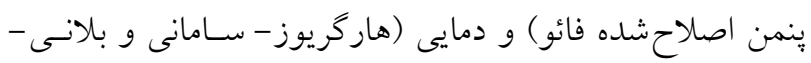

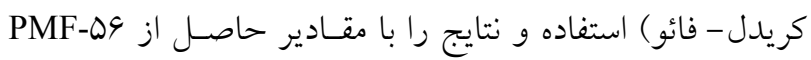

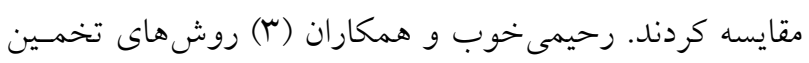

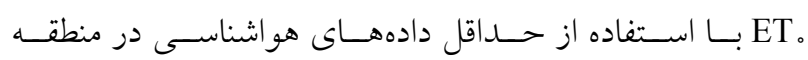
خوزستان را با استفاده از معادله هو PMF-D9 مـورد مقايسـه قـرار

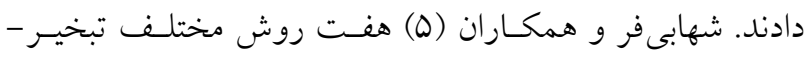

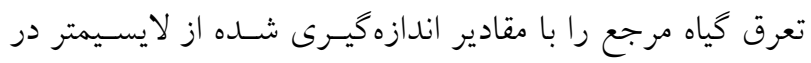

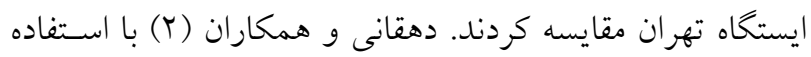

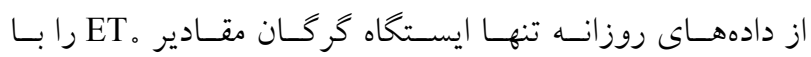

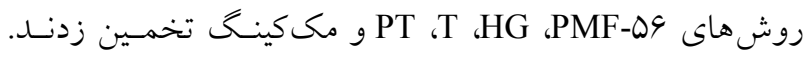
نامبردكان مدلها را براساس روش استاندارد

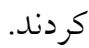
با توجه به بيشينه يزوهش بهنظر مىرسد كه مطالعه دقيسق و

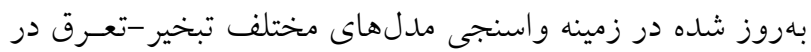
شمال غرب ايران بر مبناى مــل PMF-O9 انجـام نشـــه اسـت. بنابر اين، هدف اين مطالعه مقايسـه روشهـاى تخمسين تبخيـر - 


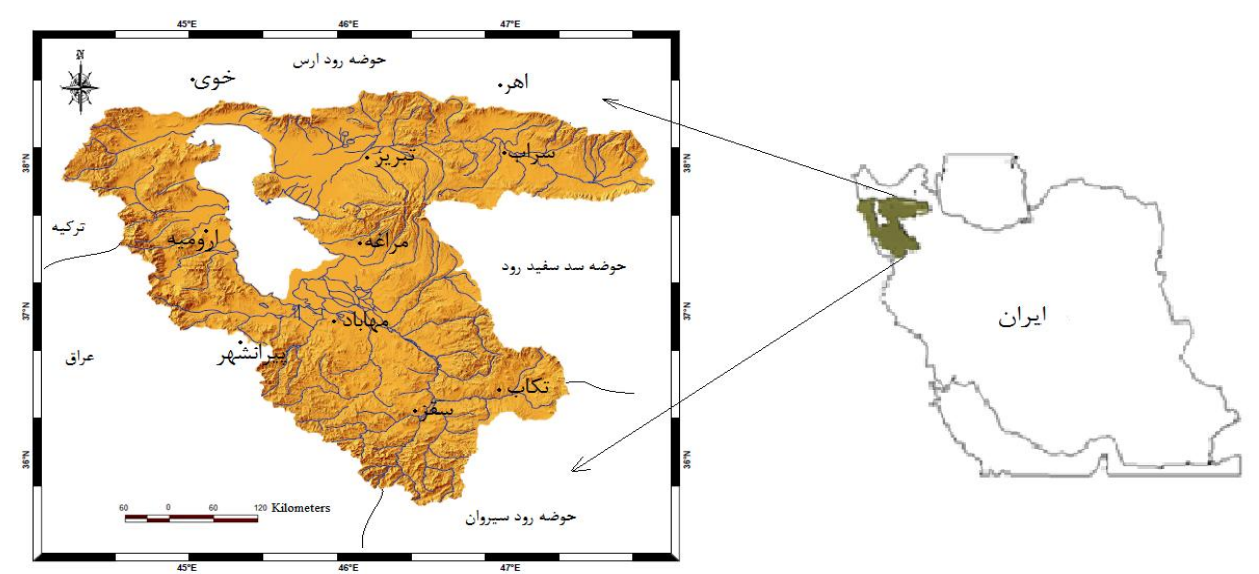

شكل 1. نقشه منطقه مورد مطالعه و موقعيت ايستخاهاى انتخاب شده در حوضه درياجه اروميه

جدول ا. مشخصات ايستخاههاى مورد مطالعه در حوضه آبريز درياجه اروميه

\begin{tabular}{|c|c|c|c|c|c|c|c|c|}
\hline \multirow{2}{*}{ دوره آمارى } & \multirow{2}{*}{ نوع اقليم } & \multirow{2}{*}{ ضريب خشكى } & \multirow{2}{*}{ ارتفاع ازسطح } & \multicolumn{2}{|c|}{ عرض جغرافيايى } & \multicolumn{2}{|c|}{ طول جغرافيايى } & \multirow{2}{*}{ نام ايستگاه } \\
\hline & & & & درجه & دقيقه & درجه & دقيقه & \\
\hline $19 \wedge 9-r_{0} \mid \circ$ & نيمهنشك & $1 T / 90$ & $1 r q \circ / 0$ & $\mu$ & rq & FV & 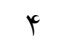 & اهر \\
\hline $19 \wedge 9-r_{\circ} \circ \wedge$ & نيمهاخشك & $1 r / \circ V$ & $110 \%$ & щ & זس & ke & $\Delta \Lambda$ & خوى \\
\hline $19 \wedge 9-r_{\circ} \circ \wedge$ & نيمه خشك & IV/OT & IrND & MG & 49 & 40 & pr & مهاباد \\
\hline $19 \wedge 9-r_{0} \mid \circ$ & نيمهاخشك & $|r / \mu|$ & I KVV/V & rV & YY & 49 & 19 & مر اغه \\
\hline $19 \wedge 9-r_{\circ} \circ \wedge$ & نيمهاخشك & $10 / 9 \varphi^{\circ}$ & $1510 / 9$ & iv & Mt & id & 0 & اروميه \\
\hline $19 \wedge 9-r_{\circ} \circ \wedge$ & نيمهاخشك & $r M / 01$ & $14 \Delta D$ & MG & yo & $\varphi 0$ & $\wedge$ & بير انشهر \\
\hline $19 \wedge 9-r_{0} \mid \circ$ & نيمهاخشك & $I r / M$ & ISAT & rV & $\Delta G$ & iv & Tr & سراب \\
\hline $19 \wedge 9-r_{\circ} \circ \wedge$ & نيمه خشك & YY/QV & DOTY/A & ra & 10 & 49 & 19 & سقز \\
\hline 19^צ-r००ᄉ & نيمهاخشك & IV/AY & $1 V 90$ & ra & r & \&V & V & تكاب \\
\hline $19 \wedge 9-r_{0} 10$ & نيمهاخشك & IY/AG & $|149|$ & ma & r & 49 & IV & ت تبريز \\
\hline
\end{tabular}

$\mathrm{ET}_{\circ}=$

$$
\frac{\circ / \kappa_{\circ} \wedge \Delta\left(\mathrm{R}_{\mathrm{n}}-\mathrm{G}\right)+\gamma \frac{\varphi_{\circ} \circ}{\mathrm{T}+r \gamma r} \mathrm{u}_{r}\left(\mathrm{e}_{\mathrm{S}}-\mathrm{e}_{\mathrm{a}}\right)}{\Delta+\gamma\left(1+\circ / r \mathrm{r}_{r}\right)}
$$

كه در آن: ET: تبخير تعرق گيـاه مرجـع ( Rn / تابش خالص درسـطح بوشـش گيـاهى (MJ m

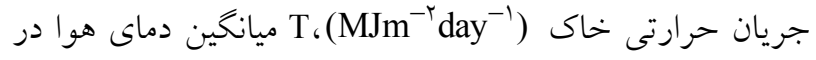

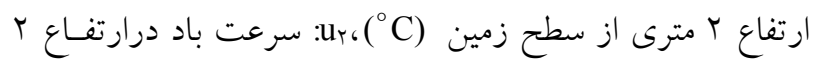

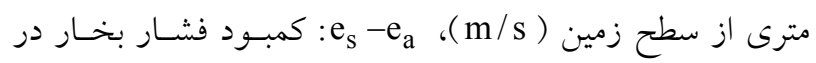

مورد مطالعه و موقعيت ايستخاههاى منتخب را نشـان مسىدهـد. جدول (1) نيز مشخصات ايستخاههاى منتخب را ارائه مى دهــد. در اين مطالعه روش PMF-OS به بعنوان روش مبنا براى مقايســ و واسنجى ساير مدلها انتخاب كرديد. علت ايـن تصـميم ايسن است كه آلن و همكاران (9)، مدل مذكور را بهعنوان يك روش استاندارد جهانى براى تخمين مET در اقليمهاى مختلف معرفى كردند. فرم توصيه شده روش 
جدول r. طبقهبندى اقليمى با توجه به ضريب خشكى دومارتن

\begin{tabular}{|c|c|c|c|c|c|c|}
\hline خيلى مرطوب & مرطوب & نيمهمرطوب & مديتر انهاى & نيمه خشك & خشك & نوع اقليم \\
\hline بيشتر از هـ & MY/99 تا TA & TV/99 تL TY & r r r/99 & 19/99 الـا & كمتر از ه1 & محدوده ضريب خشكى \\
\hline
\end{tabular}

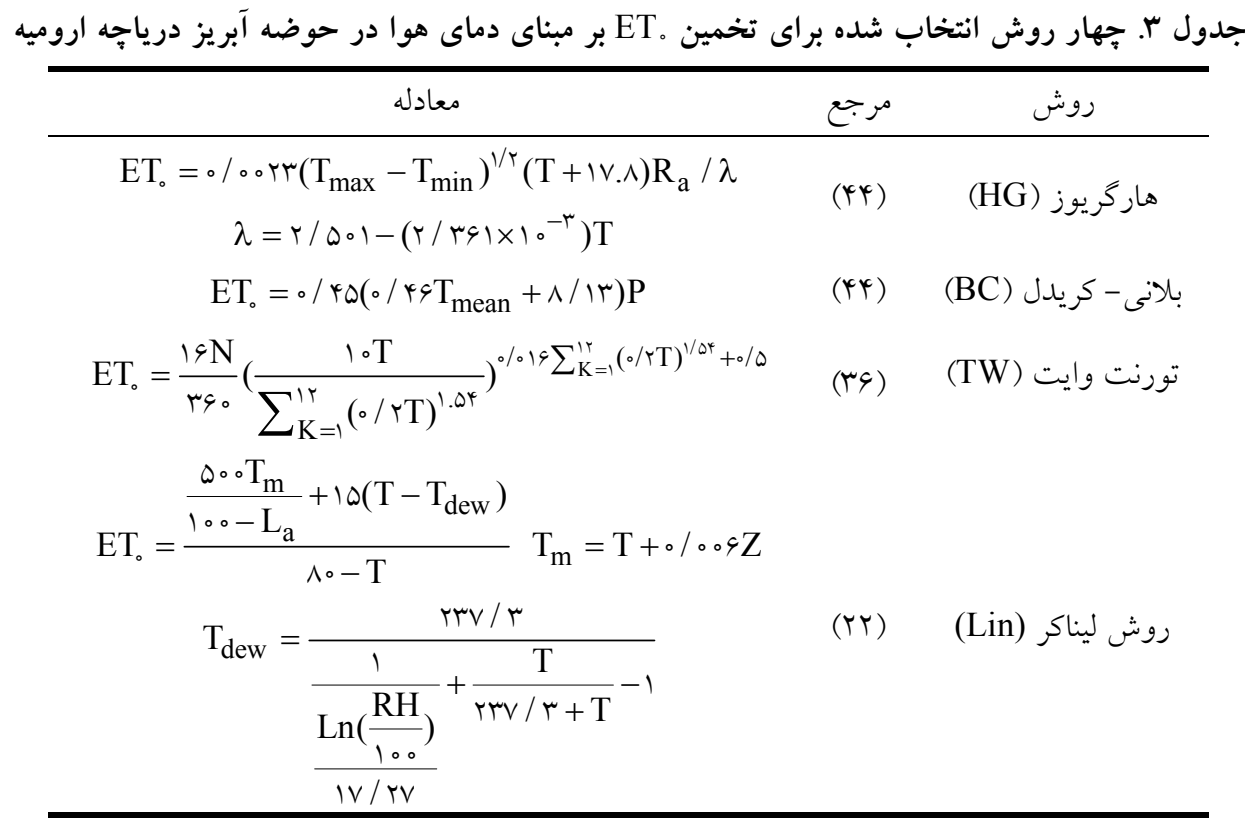

تابعى از عرض جغرافيايى محل و مـاه مـورد نظـر مسىباشـــ و

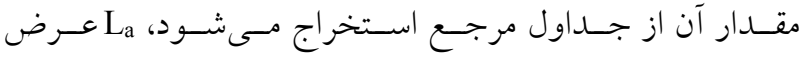

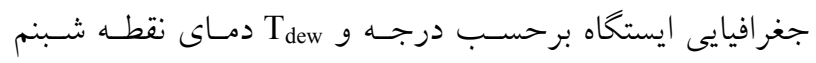

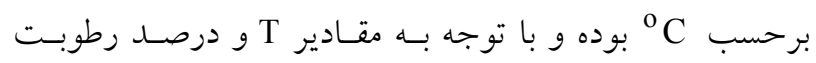

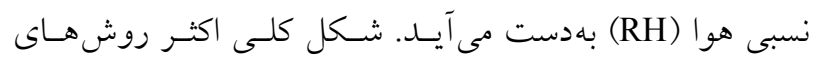
تخمين \&TT بر مبناى تابش بهشرح زير است (1N): $\lambda \mathrm{ET}_{\mathrm{o}}=\mathrm{C}_{\mathrm{r}}\left(\mathrm{wR}_{\mathrm{s}}\right) \mathrm{L}_{\text {in }} \lambda \mathrm{ET}_{\mathrm{o}}=\mathrm{C}_{\mathrm{r}}\left(\mathrm{wR}_{\mathrm{n}}\right)$

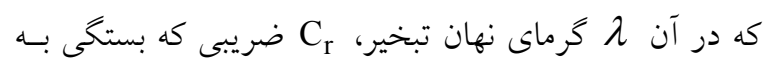
رطوبت نسبى و سرعت باد دارد، W ضريب وزنى دماى هـوا و

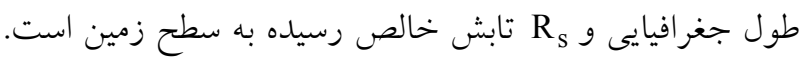
در اين مطالعه، هفت روش تخمين ET مبتنى بر تسابش آفتساب (جدول \&) براى مقايسه و واسنجى انتخاب كرديسـ. در جـدول

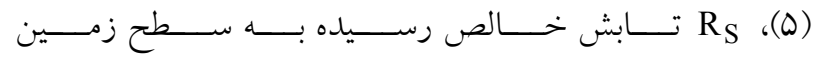

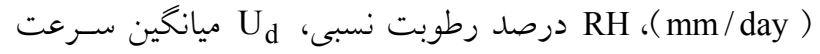
باد روزانه (m/s)، ens,max

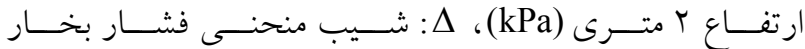

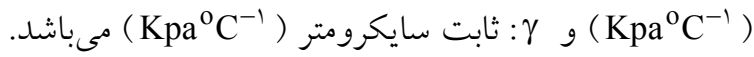
شكل كلى اكثر روشهاى تخمين ET. بر مبناى دماى هوا $\mathrm{ET}=\mathrm{C}(\mathrm{T})^{\mathrm{n}^{*}}$

$\mathrm{ET}_{\mathrm{o}}=\mathrm{C}_{1} \mathrm{~d}_{1} \mathrm{~T}\left(\mathrm{C}_{\mathrm{r}}-\mathrm{C}_{\mathrm{r}}\right)$

كه C و ل مر ايب ثابت تجربى هسـتند كـه مقـادير آنهـا را

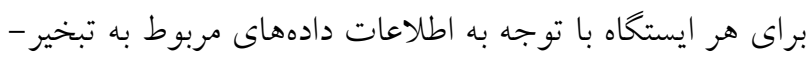

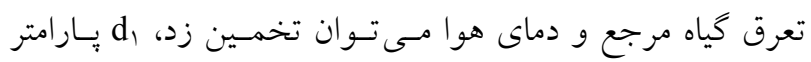

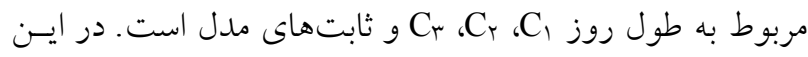

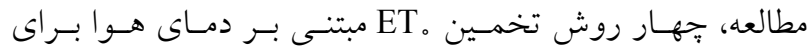

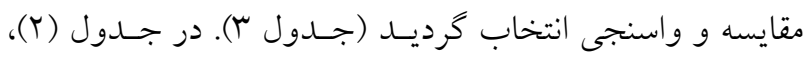

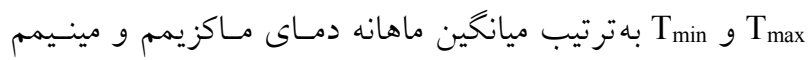

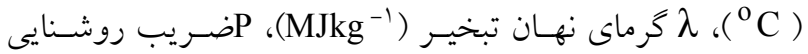

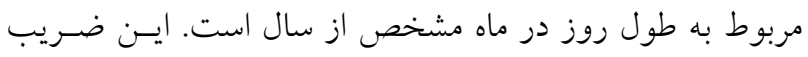


جدول Fا. هفت روش انتخاب شده براى تخمين \&T بر مبناى تابش خورشيدى در حوضه آبريز درياجه اروميه

\begin{tabular}{|c|c|c|}
\hline 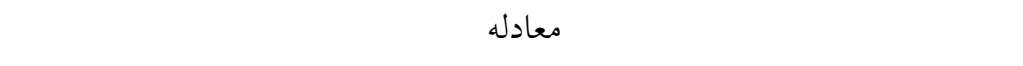 & مرجع & 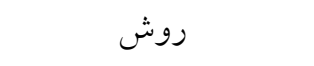 \\
\hline 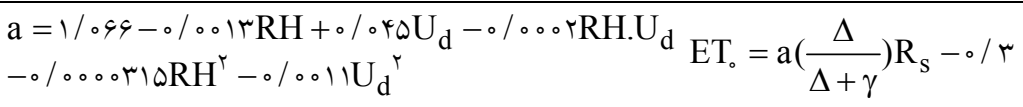 & 10 & دورنبوس - يروت (DP) \\
\hline $\mathrm{ET}_{\circ}=1 / \gamma \varphi\left(\frac{\Delta}{\Delta+\gamma}\right) \mathrm{R}_{\mathrm{n}} / \lambda$ & rA & 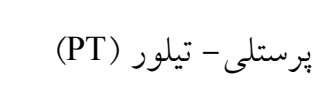 \\
\hline $\mathrm{ET}_{\circ}=\circ / 41\left(\frac{\Delta}{\Delta+\gamma}\right) \mathrm{R}_{\mathrm{S}} / \lambda-\circ / \mathrm{r}$ & TY & مك كينگ (Mak) ( ) \\
\hline $\mathrm{ET}_{。}=\mathrm{C}_{\mathrm{T}}\left(\mathrm{T}-\mathrm{T}_{\mathrm{X}}\right) \mathrm{R}_{\mathrm{S}}$ & & \\
\hline $\mathrm{C}_{\mathrm{T}}=\frac{1}{r \Delta-(\mathrm{h} / \mathrm{Irv})+\left(r q \Delta /\left(\mathrm{e}_{\mathrm{s}, \max }-\mathrm{e}_{\mathrm{s}, \min }\right)\right.}$ & 19 & جنسن - هيز (JH) ( ) ( \\
\hline$T_{X}=-r / \Delta-\circ / / r\left(e_{s, \max }-e_{s, \min }\right)-h / 10$ & & \\
\hline $\begin{array}{l}\mathrm{ET}_{\circ}=0 / 01 r \frac{\mathrm{T}}{\mathrm{T}+10}\left(\mathrm{R}_{\mathrm{S}}+0_{0}\right) \mathrm{RH} \geq 0 . \\
\mathrm{ET}_{\circ}=0 / 01 r \frac{\mathrm{T}}{\mathrm{T}+10}\left(\mathrm{R}_{\mathrm{S}}+\omega_{0}\right)\left(1+\frac{0 . \mathrm{RH}}{v_{0}}\right) \text { براى RH } \leq 0 .\end{array}$ & rq & تورى (T) ت ت (T) \\
\hline $\mathrm{ET}_{\circ}=\circ / \Delta \mathrm{R}_{\mathrm{s}} / \lambda$ & 4 & 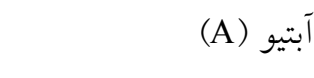 \\
\hline $\mathrm{ET}_{0}=\left\{(0 / 0 \circ \wedge r \mathrm{~T}-\circ / 19)\left(\mathrm{R}_{\mathrm{S}} / 1000\right)\right\} r / 0 r$ & rQ & مكخينز - بوردن (MB) - (MB) \\
\hline
\end{tabular}

مرجع محاسبه شـده بـا روش PMF-ه9 برحسـب (mmday ${ }^{-1}$ (m-ه در ماه معين براى سال i ام؛

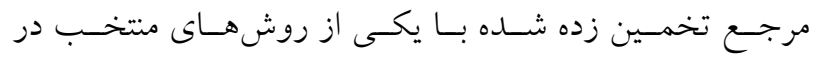
جدولهاى (r)، (Y) و (ه)؛ كيـاه مرجــع تخمسين زده شـده بـا روش سالهاى آمارى مىباشد. در اين مطالعه با برازش خط رگرسيون

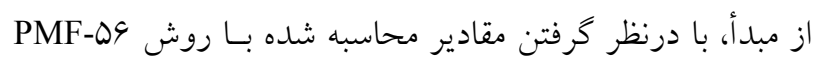
بهعنـوان متغيـر وابسـته و مقـادير حاصـل از يـكـ روش معسين بهاعنوان متغير مسـتقل، شـيب خــط ركرسـيون از مبــأ (زاى و همكاران) محاسبه شد و بهعنوان ثابت واسنجى (K) براى روش مورد نظر بهدست آمد. آنخاه مقدار ضريب تبيسين محاسـبه شـد. اين كار براى يكايك ايستخاهها انجام شد. در اين بزوهش براى تعيين اقلـيم ايستخاههـاى منتخـب از ضريب خشكى دومارتن استفاده شد. كه مدل كلى آن بهصورت زير مىباشد. $\mathrm{I}=\frac{\mathrm{P}}{\mathrm{T}+1 \text { 。 }}$

ضريب خشكى دومـارتن، P: ميـانكين بارنـدكى سـاليانه
متناظر با حداكثر و حــاقل دمـاى هــوا در گرمتـرين مـاه سـال

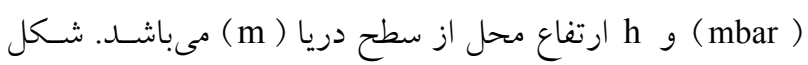
كلى اكثر روشهاى تخمين مET بر مبناى انتقال جـرم بـهــرح

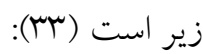
$\mathrm{ET}_{\circ}=\mathrm{C}\left(\mathrm{e}_{\mathrm{s}}-\mathrm{e}_{\mathrm{a}}\right)$

كه در آن C ضريب ثابتى است كه به سرعت باد بستخى دارد. روش هاى انتخاب شده براى تخمين •ET كه بر مبناى انتقال جرم مىباشند در جــدول (ه) ارائسه شـدهانـد. در ايسن جــدول، كميت نيز سرعت باد در ارتفاع r مترى مىباشد. در اين مطالعه ب معيار ارزيابى شـامل R R (ضـريب تعيـين)، RMSE (جذر ميانخين مربعات خطا)، MBE (ميـانخين خطساى اريب) و MAE (ميانخين خطـاى مطلـق) اسـتفاده شـــه اسـت. معادله هر كدام از اين معيارها در جدول (9) ارائسه شـده اسـت. در جدول (9)، ETom,i مقدار تبخير - تعرق گياه مرجع تخمين زده شده با يكى از روشهـاى دمـايى برحسبـ(mmday ${ }^{-1}$ در

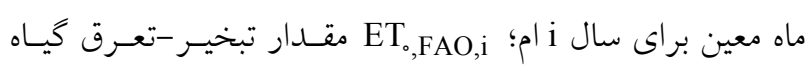


جدول ه. روشهاى انتخاب شده براى تخمين \&T بر مبناى انتقال جرم در حوضه آبريز درياجه اروميه

\begin{tabular}{|c|c|c|c|c|c|}
\hline معادله & واحد $)$ & $\begin{array}{l}\text { واحد } \\
\left(u_{Y}\right)\end{array}$ & مرجع & 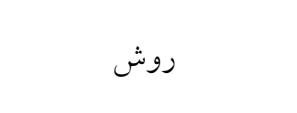 & رديف \\
\hline$E T_{\circ}=\left(\circ / r v \omega+\circ / \circ \Delta \circ r \varphi u_{r}\right) \cdot\left(e_{s}-e_{a}\right)$ & $\mathrm{hPa}$ & $\mathrm{m} / \mathrm{s}$ & TS & 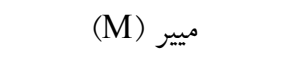 & 1 \\
\hline $\mathrm{ET}_{\circ}=\left(\circ / r q r \Lambda+\circ / \circ V r r r u_{r}\right) \cdot\left(\mathrm{e}_{\mathrm{s}}-\mathrm{e}_{\mathrm{a}}\right)$ & $\mathrm{hPa}$ & $\mathrm{m} / \mathrm{s}$ & M & دالتون (D) & r \\
\hline $\mathrm{ET}_{0}=0 / \mathrm{rr}^{r}\left(1+\circ / r v \mathrm{u}_{Y}\right) \cdot\left(\mathrm{e}_{\mathrm{S}}-\mathrm{e}_{\mathrm{a}}\right)$ & $\mathrm{mm} \mathrm{Hg}$ & $\mathrm{m} / \mathrm{s}$ & rq & روهور (R) & r \\
\hline$E T_{\circ}=\circ / r \Delta\left(1+\circ / q \wedge / 1 \circ \circ u_{r}\right) \cdot\left(e_{s}-e_{a}\right)$ & $\mathrm{mm} \mathrm{Hg}$ & $\begin{array}{c}\text { Mile/da } \\
y\end{array}$ & TV & ) بينمن (P) & $\varphi$ \\
\hline $\mathrm{ET}_{0}=\circ / \Delta \mu r / \mathrm{u}_{r} / \kappa \Delta \varphi \cdot\left(\mathrm{e}_{\mathrm{S}}-\mathrm{e}_{\mathrm{a}}\right)$ & $\mathrm{hPa}$ & $\mathrm{m} / \mathrm{s}$ & 11 & بروكمبٍ و وننر (BW) & 0 \\
\hline $\mathrm{ET}_{\circ}=\circ / 10 \cdot v r \cdot \sqrt{r / 9 \mathrm{u}_{r}} \cdot\left(\mathrm{e}_{\mathrm{s}}-\mathrm{e}_{\mathrm{a}}\right)$ & $\mathrm{hPa}$ & $\mathrm{m} / \mathrm{s}$ & r & 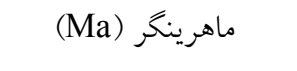 & 9 \\
\hline $\mathrm{ET}_{\circ}=\circ / \mathrm{r}_{\circ} \mathrm{v} \cdot \sqrt{\mathrm{u}}_{\mathrm{r}} \cdot\left(\mathrm{e}_{\mathrm{s}}-\mathrm{e}_{\mathrm{a}}\right)$ & $\mathrm{hPa}$ & $\mathrm{m} / \mathrm{s}$ & rv & ترابرت (Tr) & V \\
\hline $\mathrm{ET}_{0}=\left(\circ / / r q \Lambda+\circ / \circ q r r_{r} u_{r}\right) \cdot\left(e_{s}-e_{a}\right)$ & $\mathrm{hPa}$ & $\mathrm{m} / \mathrm{s}$ & ro & WMO & $\wedge$ \\
\hline$E T_{0}=\left(0 / 100 \Delta+\circ / r q \vee u_{r}\right) \cdot\left(e_{s}-e_{a}\right)$ & $\mathrm{hPa}$ & $\mathrm{m} / \mathrm{s}$ & $\wedge$ & آلبر جت (Al) & 9 \\
\hline
\end{tabular}

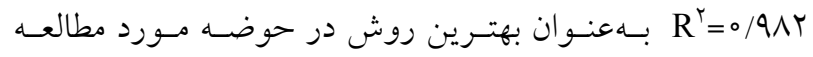

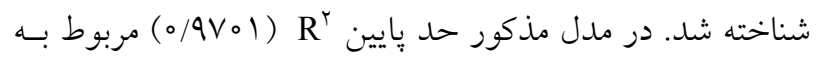

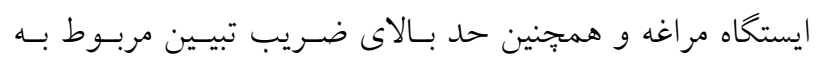

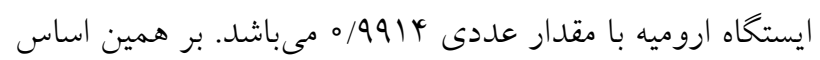
نتايج روش DP در ادامه ارائه مىشود. قبل از واسنجى روشهاى تخمين تبخير - تعرق گياه مرجـع

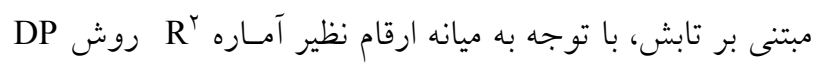

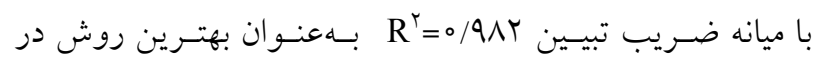
حوضه مورد مطالعه شناخته شد. يـس از روش DP روشهـاى

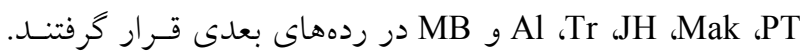

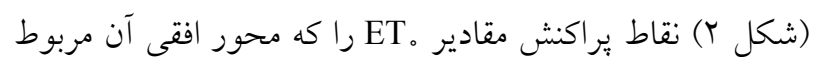

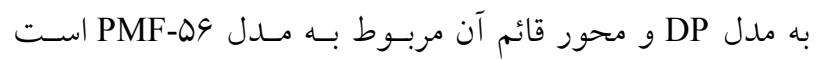
نشان مى دهد. بهطورى كه از اين شكل مىتوان استنباط كرد مدل دورنبوس يرويت قبل از واسنجى مقدار 。ET را بـا دقـت قابـل

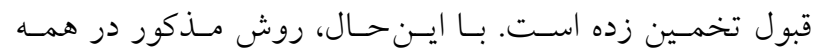
ايستخاهها مقـدار 。 ET را بيشـتر از مـدل PMF-PMF تخمسين زده است. علت آن اين است كه مقدار \&T با روش

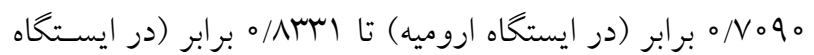
تبريز) روش نظيـر DP تغيـر مسى كنـد. جــدول (9) معيارهـاى
برحسب ميلى متر و T: ميانخين دمـاى هـواى سـاليانه برحسـب

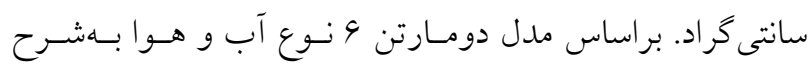
جدول (Y) طبقهبندى و تعريف شدهاند: بهمنظور صحتسنجى روشها، كل دوره آمارى به دو بخش طورى تقسيم شد كه قسمت اول شـامل دوره آمـارى منهـاى ه سال آخر و قسمت دوم دادههاى ه سال آخر بـود. آنخـاه يكبـار ديخر مدلسازى با دادهاى قسمت اول انجام شد و با توجه بـــ ضرايب واسنجى مدل، صحتسنجى آن با دادههاى قسمت دوم

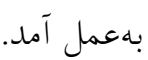

\section{نتايج و بحث}

در اين قسمت نتايج واسنجى روش ها بهصورت دستهبندى شده ابتدا براى روشهاى بر مبناى درجه حرارت هـوا، سـيس بـراى روشهاى بر مبناى تابش و در خاتمه روشهاى بر مبناى انتقال جرم انجام شد. كه از بين اين سه دسته كلى روشهاى بر مبناى تابش بنهنوان بهترين دسته كلى معرفى شد. بـراى هـر ايسـتخاه مقدار ضريب تعيين بهدست آمـا و در بـين ها ايسـتخاه مقــدار ميانه ضريب مذكور درنظر گرفته شد. از بين روشهاى بر مبناى تابش روش دورنبـوس - يـروت (DP) بـا ميانـه ضـريب تبيـين 


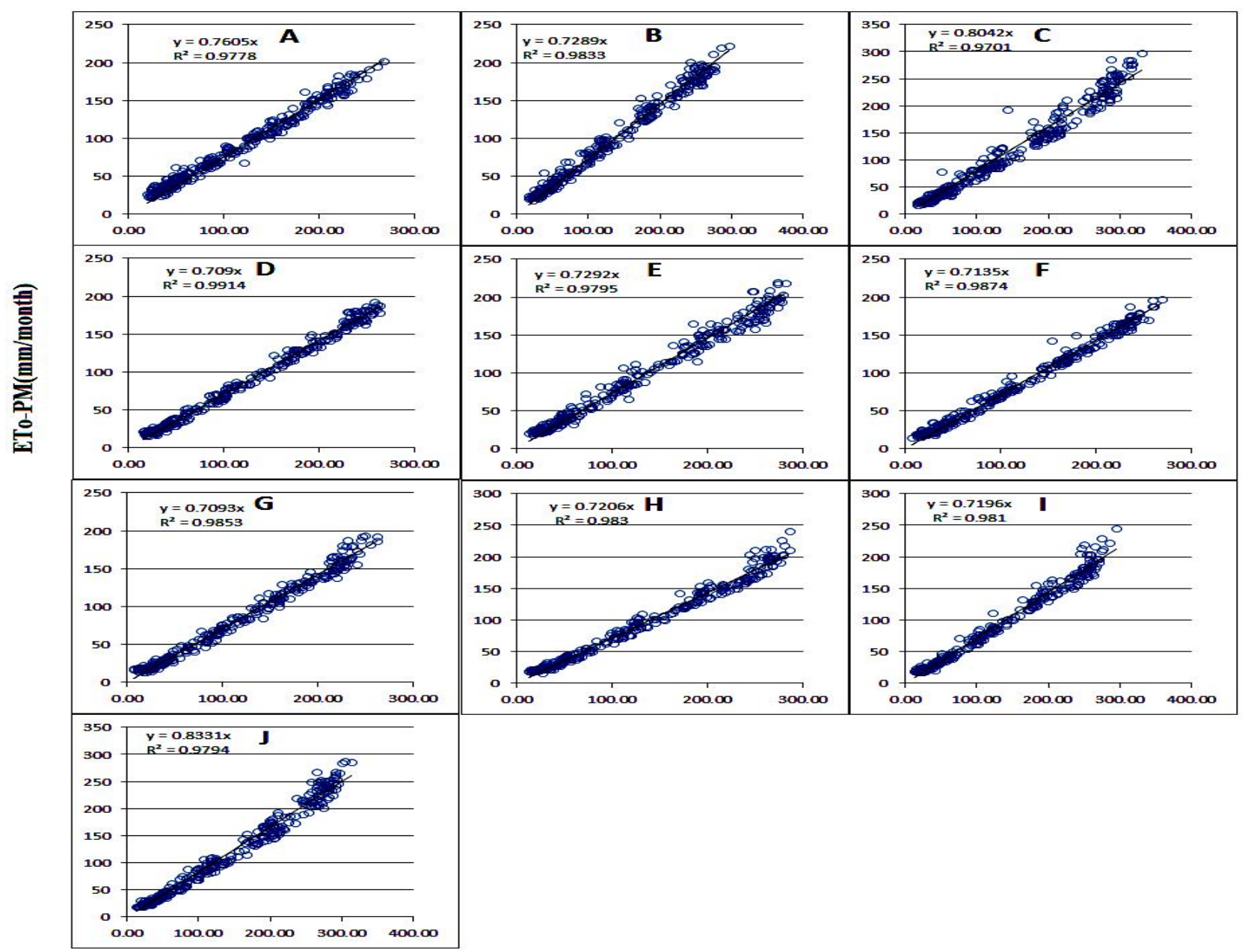

ETo-DP(mm/month)

شكل Y. مقايسه مقادير م محاسبه شده با روش دورنبوس - يروئيت (DP) و PMF-ه9 در

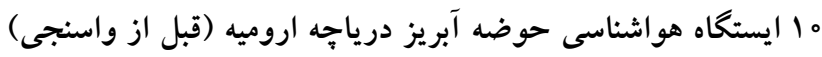

جدول 9 .آمارههاى ارزيابى عملكرد مدلهاى مورد استفاده در اين مطالعه

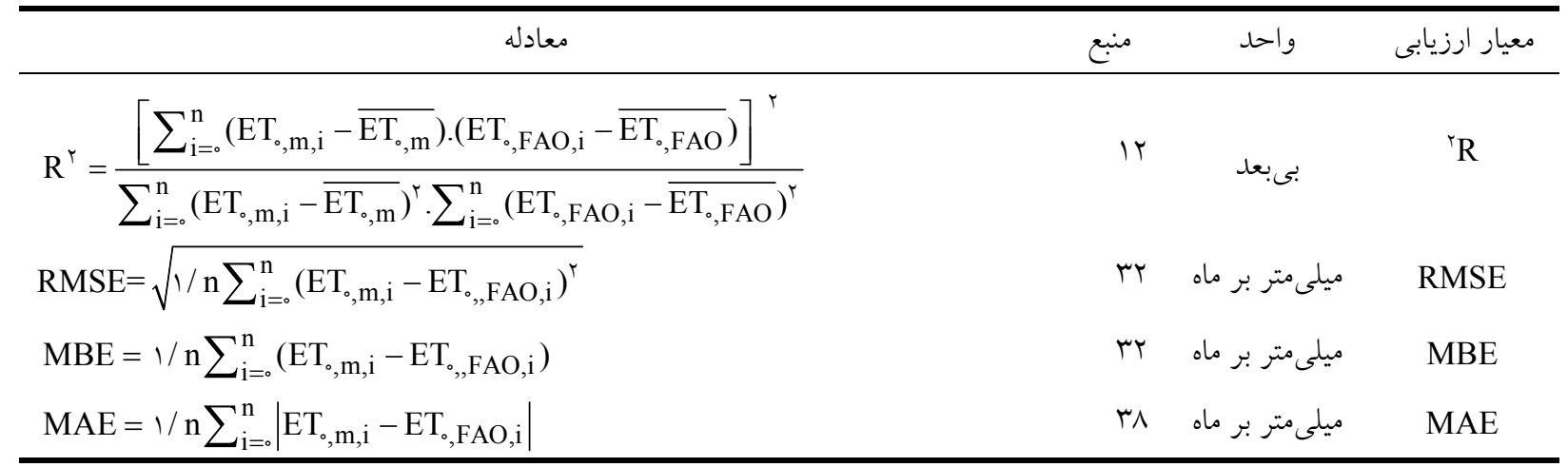

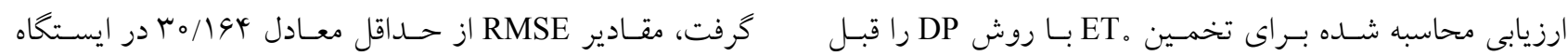

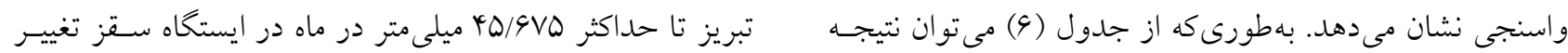




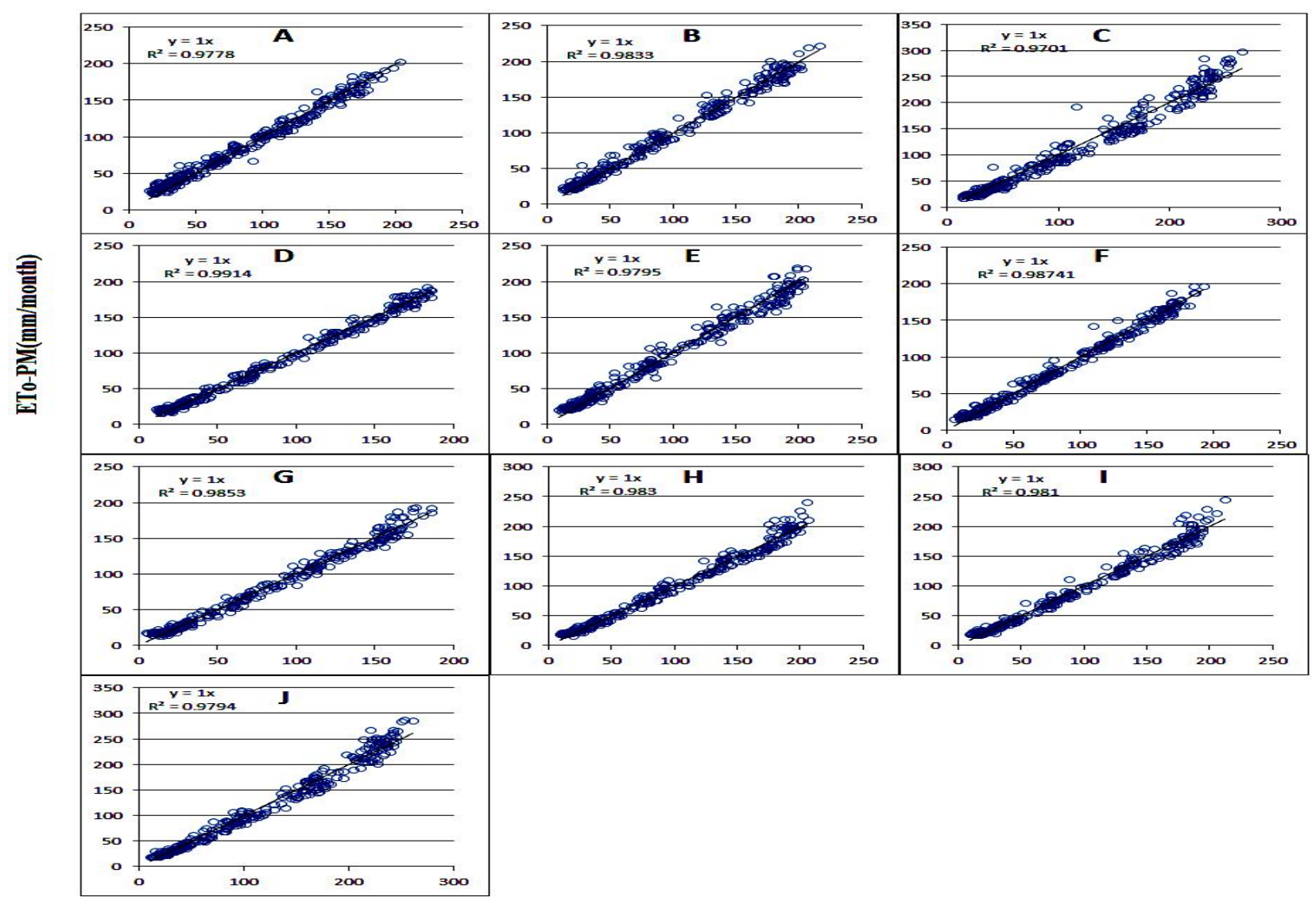

ETo-DP(mm/month)

شكل r. مقايسه مقادير ET محاسبه شده با روش دورنبوس- يروئيت (DP) و PMF-ه9 در

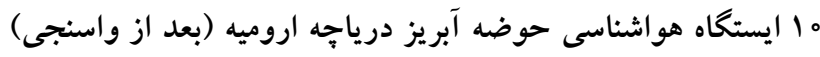

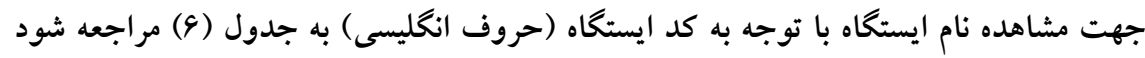

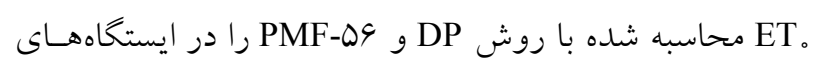

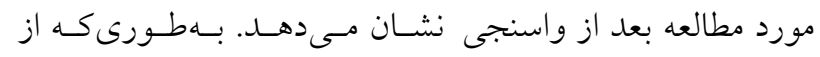
شكل (r) مسى تـوان اسـتنباط كـرد، يسس از واسـنجى، مقــادير

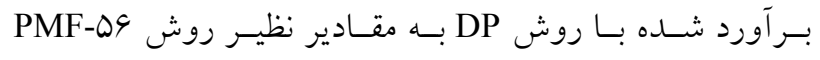

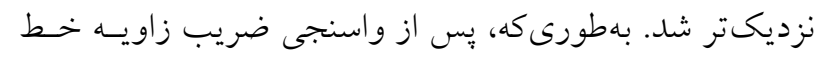

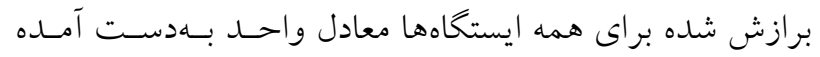

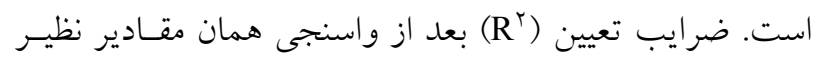

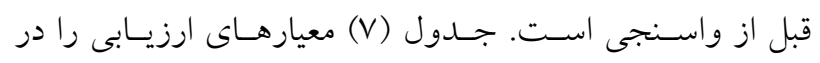

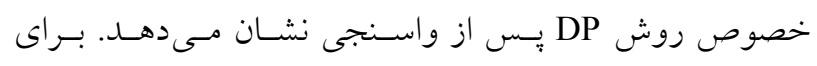

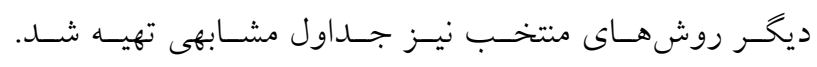

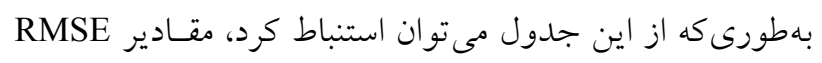

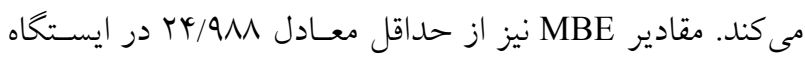

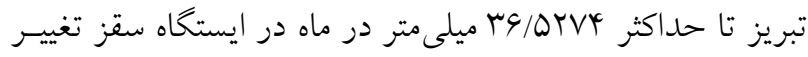

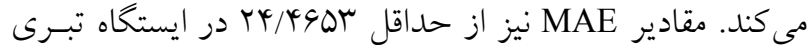

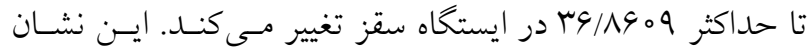
مى دهد كه در ايستخاه مذكور ميانخين قدر مطلق انحراف مقادير

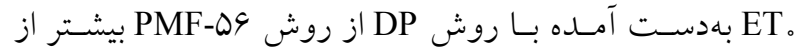

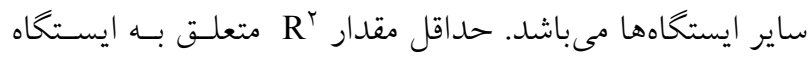

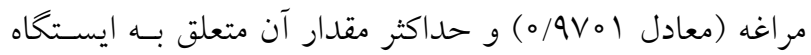

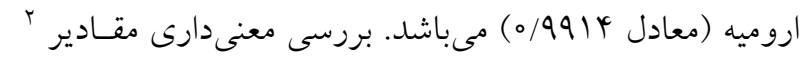

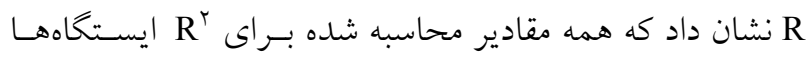

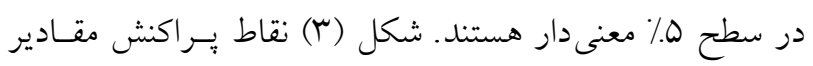


جدول V. معيارهاى ارزيابى محاسبه شده براى تخمين ET با روش DP در ايستخاههاى حوضه آبريز درياجه اروميه (قبل از واسنجى)

\begin{tabular}{|c|c|c|c|c|c|}
\hline MAE & $\mathrm{MBE}$ & RMSE & $\mathrm{R}^{r}$ & كد ايستخاه & نام ايستخاه \\
\hline KGNYV & TO/MAKT & $r Y / 9 \wedge Q_{0}$ & - /qVVA & A & اهر \\
\hline rQ/RVTQ & $r Y / q \Delta \wedge 1$ & $\langle r / Q \wedge V q$ & . & B & مهاباد \\
\hline$r q / 19 \circ r$ & $r q / 1 r q 9$ & $r 4 / 4900$ & $0 / 9 V 01$ & $\mathrm{C}$ & مر اغه \\
\hline$r \Delta / v a 1 \wedge$ & $r \Delta / 9 Y \circ \Lambda$ & $r \mu / T V I T$ & $0 / 9914$ & D & اروميه \\
\hline$r \mu / 919 \mu$ & $\mu \varphi / 1110$ & $4 r / 0<q 9$ &.$/ 9 \vee 90$ & E & بيرانشهر \\
\hline 年/ & TY/GVYG & $r \circ / 9 \circ V r^{c}$ &.$/ 9 \wedge V^{4}$ & $\mathrm{~F}$ & سراب \\
\hline rT/QYqA & rY/Q/YO & Y०/GATV & -/QAQR & G & خوى \\
\hline$r 4 / 19.9$ & TG/OTVE & $\varphi Q / \circ 9 V Q$ & ०/Q४r. & $\mathrm{H}$ & سقز \\
\hline rG/TYK & $r \Delta / 9011$ & $k 4 / 0 \mid+q$ &.$/ 9110$ & I & تكاب \\
\hline$r Y / 49 \Delta R$ & $T Y / Q \Lambda \Lambda$ & $r_{0} / 194$ & - /qVq4 & $\mathrm{J}$ & تبريز \\
\hline$\mu \psi / \Lambda \mu_{0}$ & $r \Delta / \Delta \mid T V$ & Fr/lTqK & O/QAYO & - & ميانه \\
\hline
\end{tabular}

(Median)

$$
\text { در جدول فوق واحد همه ارقام (بهغير از ارقام نظير R ميلىمتر در ماه است. }
$$

جدول ^. معيارهاى ارزيابى محاسبه شده براى تخمين ET با روش DP در ايستخاههاى حوضه آبريز درياجه اروميه (بعد از واسنجى)

\begin{tabular}{|c|c|c|c|c|c|}
\hline MAE & MBE & RMSE & $\mathrm{R}^{r}$ & كد ايستخاه & نام ايستخاه \\
\hline$\Delta / \wedge \Delta \Delta V$ & $-Y / 91 Y$ & VMTYG & $\circ / 9 V V A$ & A & اهر \\
\hline 9/0HT & $-1 / 4 \circ{ }^{\prime} \Lambda$ & $V / 9 V \wedge r$ & ס/914r & B & مهاباد \\
\hline 1./FYTD & $1 / 9 \wedge 4$ & IT/ATHY & $0 / 9 V 01$ & $\mathrm{C}$ & مر اغه \\
\hline $4 / \pi / 19$ & $-o / D \& V \mid$ & $0 / \Gamma 190$ &.$/ 9914$ & $\mathrm{D}$ & اروميه \\
\hline אחו 9/9 & $-1 / 91 \cdot \Lambda$ & $1 / 9911$ &.$/ 9 \vee 90$ & $\mathrm{E}$ & بير انشهر \\
\hline Y/OVVA & $-1 / 1014$ & $9 / \pi 49$ & $0 / 9 \wedge V^{4}$ & $\mathrm{~F}$ & سراب \\
\hline Y/qAY & $-0 / 90 \mathrm{VV}$ & $9 / 40 \cdot 0$ & 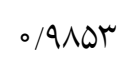 & G & خوى \\
\hline $9 / \pi \circ 90$ & $-0 / \Delta M M r$ & N/l०Y。 & ॰/9Ar。 & $\mathrm{H}$ & سقز \\
\hline 9/0HTY & $-0 / \mu \circ r\}$ & N/GTYO &.$/ 911$. & I & تكاب \\
\hline N/DFYY & $\circ / \Lambda \wedge V D$ & $11 /$ TVAr & -/9vqF & $\mathrm{J}$ & تبريز \\
\hline 9/0MTY & - O/GYTa & $V / \wedge q \circ r$ & -/AAY & - & ميانه (Median) \\
\hline
\end{tabular}

جهت مشاهده نام ايستخاه با توجه به كد ايستخاه (حسروف

انخليسى) به جدول (9) مر اجعه شود. بهعنوان مثال، مقدار آماره

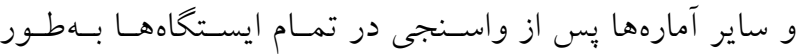

$$
\begin{aligned}
& \text { محسوسى كاهش يافته است. }
\end{aligned}
$$



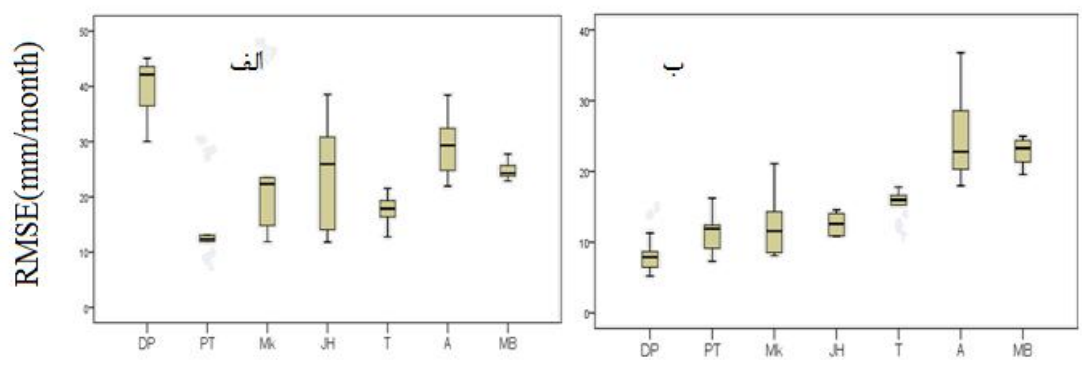

شكل ثل. نمودار باكس - ويسكر آماره RMSE براى روشهاى تخمين \& بر مبناى تابش: الف) قبل از واسنجى و ب) بعد از واسنجى

جدول 9. در ايستخاههاى حوضه آبريز درياجه اروميه

\begin{tabular}{|c|c|c|c|c|c|c|c|c|c|c|}
\hline تبريز & تكاب & سقز & خوى & سراب & بير انشهر & اروميه & مر اغه & مهاباد & اهر & ايستگاه \\
\hline ו ו ותות & $0 / 2199$ & $\circ / V Y \circ 9$ & $\circ / N \circ r_{q}$ & ०/VITL & -NTAT & $\circ / V \circ 90$ & O/AOKT & ०/VYAQ & $\circ / N 9 \circ D$ & DP \\
\hline $1 / T Y \circ 9$ & 1/०rvq & $1 / 0 r \circ r$ &.$/ 91 Y V$ & ०/9१Q9 & $1 / T V q$ & $\circ / 90.1$ & I/AVG & $1 / 001 Y$ & $1 / 191$ & PT \\
\hline $1 / 4 Y Q S$ & $1 / T \circ \circ V$ & $1 / 1994$ & $1 / \circ \wedge \uparrow \wedge$ & I/IMVA & $1 / \pi 100$ & $1 / 11 \circ 1$ & $1 / 4 \circ 41$ & l/Nץq & $1 / \Gamma \circ \mu_{0}$ & M \\
\hline $1 / 0019$ & ०/V9A1 & $\circ / V \Delta \wedge r$ & $\circ / V V \wedge \Delta$ & -/NYQD & -/NTAG & O/AYIr & ./911Y & $\circ / \Lambda \circ \circ 4$ & ०/99TV & $\mathrm{JH}$ \\
\hline I/IYHA & $0 / 9 V 49$ & ./90r4 & $\circ / 9 \mu \circ 1$ & $|/ 9 \mu|$ &.$/ 9411$ & $0 / 9190$ & $1 / 0949$ & ./91^r & $1 / 0 V 90$ & $\mathrm{~T}$ \\
\hline $1 / 11 \wedge 9$ & -/AVGA & $\circ / 1 \wedge 9 \Lambda$ & O/AYMG & O/ATMG &.$/ 9410$ & - /ATTQ & $1 / 0909$ &.$/ 91$ HY & ०/MVVG & A \\
\hline $1 / 0 \wedge \cdot 1$ & I/TVA & $1 / 0049$ & $\circ / \Lambda Y^{\prime} \circ T$ & $1 / 0400$ &.$/ 940$. & -/^৭০r & $1 / 094 A$ & $\circ / 91 Y_{0}$ & $1 / 9 V$ & MB \\
\hline
\end{tabular}

RMSE بعد از واسنجى براى هر يك از روشها بـهـــور قابـل

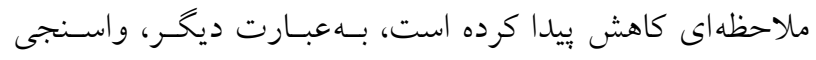
روش هاى مختلف تخمين مET بر روى دقت تخمين روش هاى مذكور بسيار مؤثر بوده است جدول (^) ضرايب واسنجى هفت روش تخمين مET را كه مبتنى بر دادههاى تابش مىباشـند بـراى ده ايستخاه منتخـب در حوضه درياجه اروميه نشان مىدهد. بهطورى كه از ايسن جـدول مى توان نتيجه كرفت، مقدار ضرايب واسنجى همه ايستخاهها بـا روش DP كمتر از واحد است بنابراين، در حوضه مورد مطالعسه

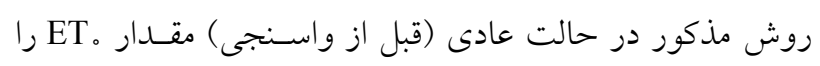
بيشتر از روش PMF-OS تخمين مىزند. در نتيجـه بــراى بهبـود عملكرد اين روش لازم است مقادير مT Eسهـ ضـريب واسـنجى مندرج در جدول (N) ضـرب شـوند. در حسالى كـه روش M در
RMSE روش DP در ايستخاه اروميه از س/ مه (قبل از واسنجى) به رقم / ه ميلى متر در ماه (يس از واسنجى) كاهش يافته است بهطور كلى، مىتوان نتيجه گرفت كه عملكرد روشهـاى مـورد

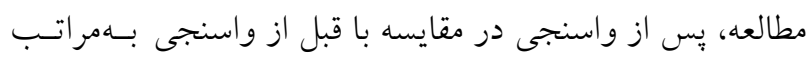
بهبود يِيدا كرده است. شـكل (Y) نمـودار بـاكس ويسكر آمـاره RMSE براى هفت روش تخمسين مET بـر مبنـاى تـابش (DP،

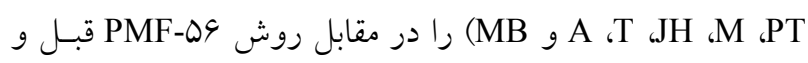
بعد از واسنجى نشان مىدهد. بهطورىكه از اين شكل مسىتـوان استنباط كرد، قبل از واسنجى ميانه سرى مربوط به ارقام RMSE

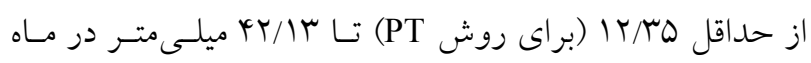
(براى روش DP) تغيير مى كند و همجينين بعد از واسنجى ميانـه

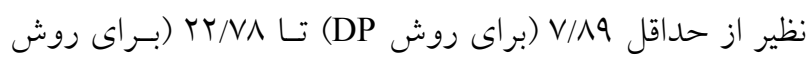
تغيير مى كند. بنابراين، مىتوان نتيجه كرفت كه مقادير آمـاره 


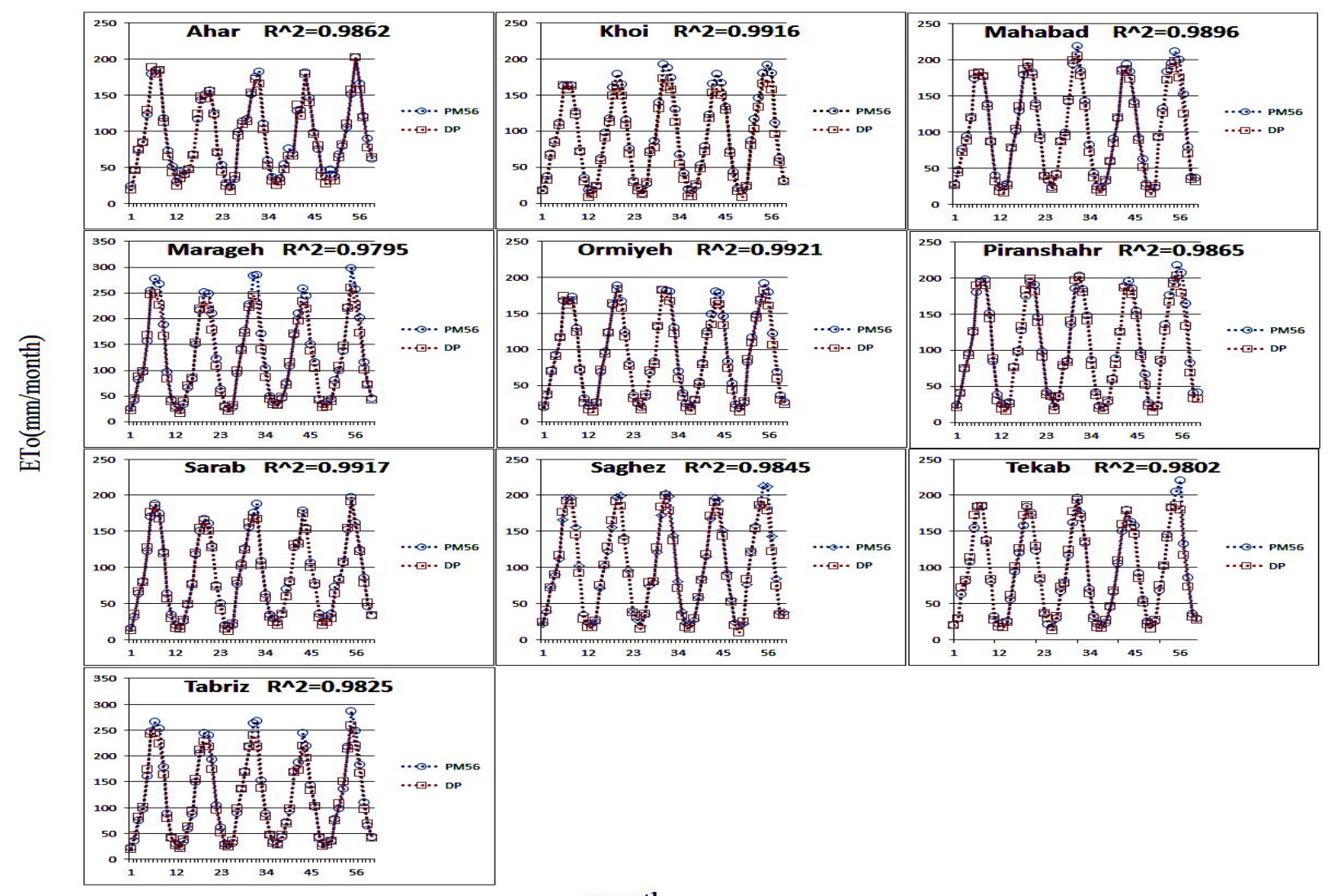

month

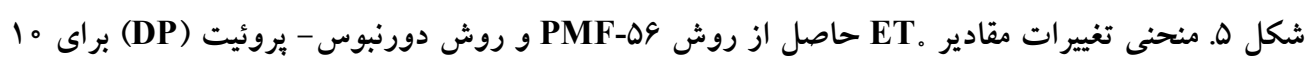

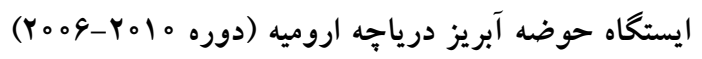

بهترتيب در ردههاى يك تا هفت قرار كرفتند.

در اين قسمت نيز نتايج مربوط بـه صسحتسـنجى روشهـا

براى ب گروه كلى ابتدا براى روشهاى بر مبناى درجه حـرارت

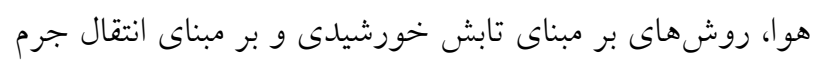

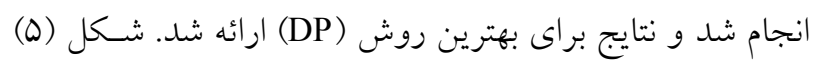
مقادير ET حاصسل از روش كT

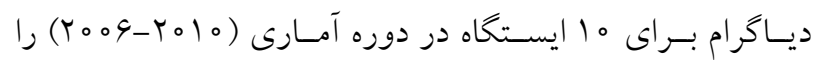
نشان مى دهد. شكل هاى مشابهى براى روشهاى ديخر تهيه شد، ولى جون ميانه آمارههاى واسنجى روش هاى ديخر از خـروه بـر

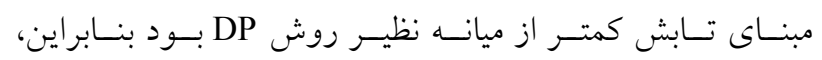
شكلهاى مذكور ارائه نخرديد. شكل (9) دياگر ام نقاط بــر اكنش مقادير تبخير - تعرق كياه مرجع واسـنجى شـده بـا روش DP و

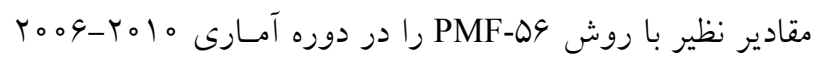

حالت عادى با توجه به دارا بودن ضرايب واسنجى بـزرگتـــ از

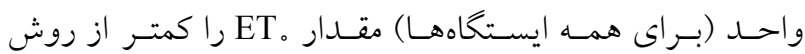
PMF-ه9 تخمين مىزند و در نتيجه براى بهبـود عملكــرد ايسن روش لازم است ارقام بهدست آمده با روش M به مقدار ضريب واسـنجى هـر ايستخاه (طبـق جـــول ^) ضـرب شـوند. سـاير روش ها در برخى ايستخاههـا داراى ضـريب واسـنجى كمتـر از واحد و در برخى ايستخاههـا داراى ضـريب واسـنجى بيشـتر از

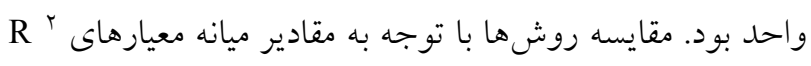
و RMSE دو به دو انجام شد. نتايج نشان داد كـه روش DP در رتبه نخست (به شرط اعمال ضـريب واسـنجى ايستخاه) قـرار كرفـت. روشهـاى PT و M در رتبـههــاى دوم و سـوم قــرار

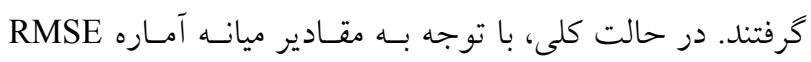

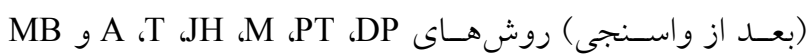




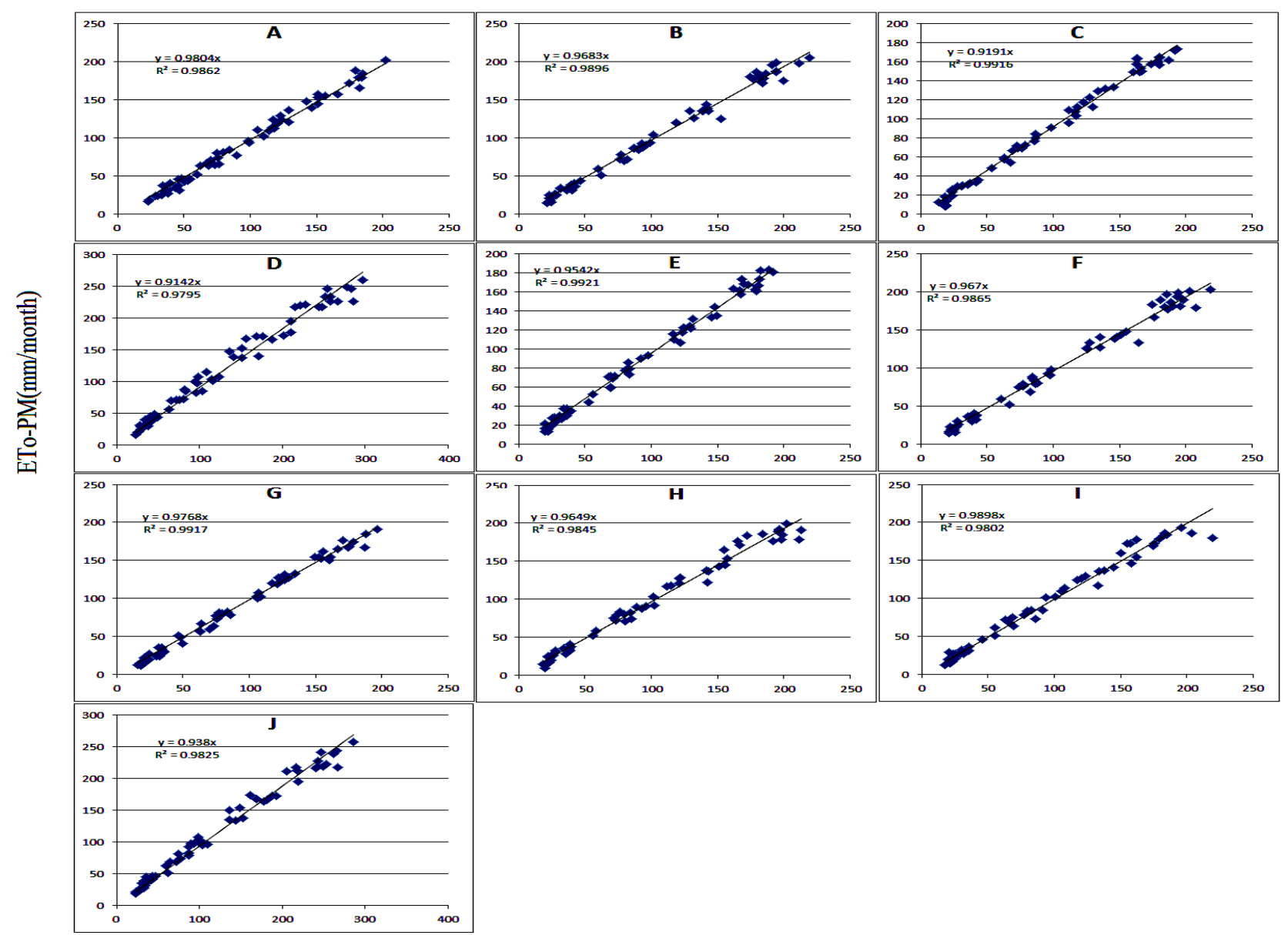

ETo-DP(mm/month)

شكل צ. مقايسه مقادير \&WT محاسبه شده با روش DP پِ از اعمال ضرايب واسنجى و PMF-ه9 در ايستخاههاى هواشناسى

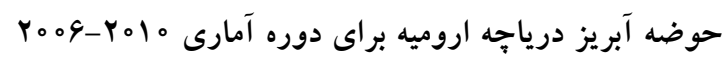

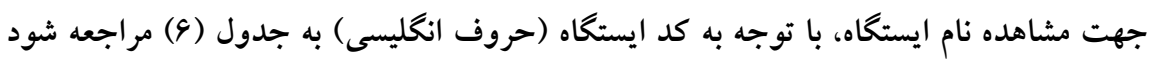

براى همه ايستخاهها نشان مى دهد. بـهـطـورىكـه از ايسن شـكل و روش تورى (مبتنى بر تابش) براى اين ناحيه مناسب است.

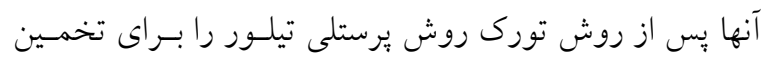

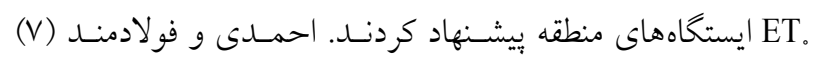

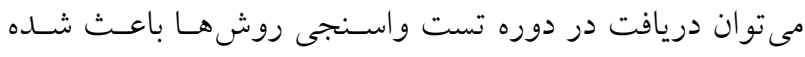

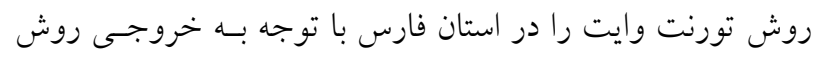

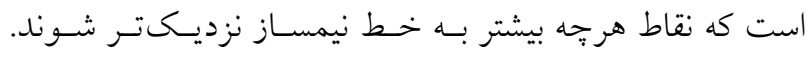

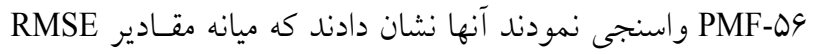

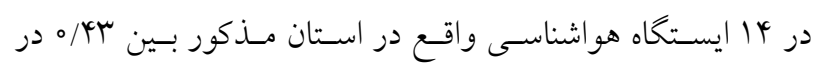

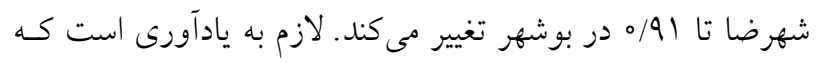

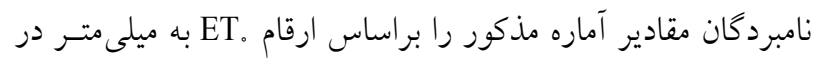

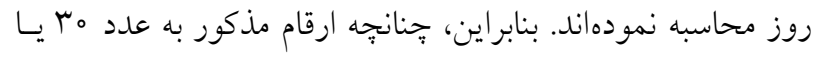

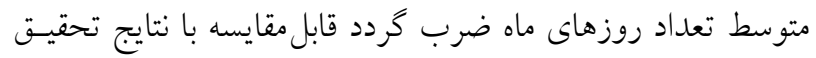
جهانبخش اصل و همكاران (1) نشان دادند كه در ايستكاه تبريز

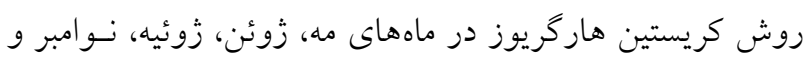
دسامبر بهعنوان بهتـرين روش تخمسين .ET اسـت. بايسـ توجـهـ

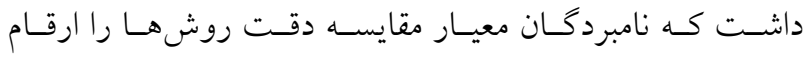

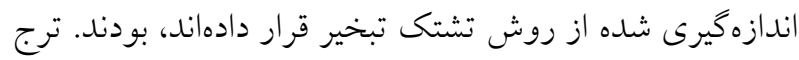

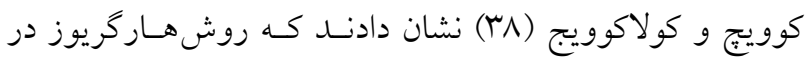
تخمين ET نواحى مرطوب صربستان و كرواسى مناسب نبـوده 


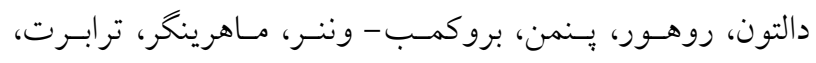

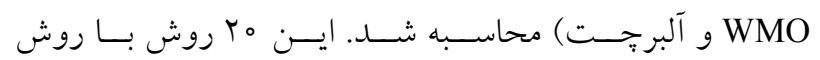

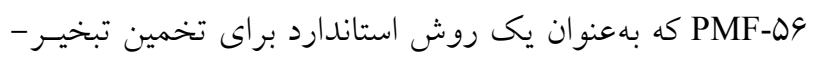
تعرق گياه مرجع توصيه شده است، مقايسه و بـراى ده ايستشكاه

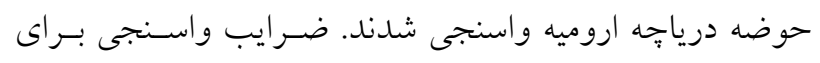
بهترين روش هر كروه در ايستخاههاى مختلف ارائه شد. مقايسه

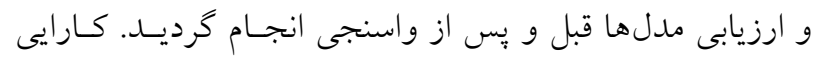

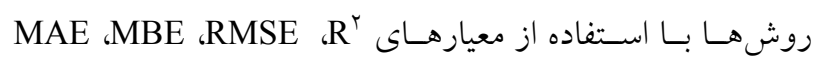

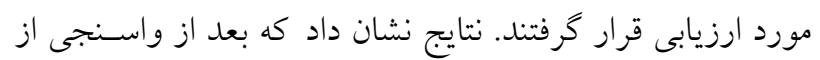
روش هاى مبتنى بر دماى هوا، روش هـاركريوز بـا ميانـه آمـاره

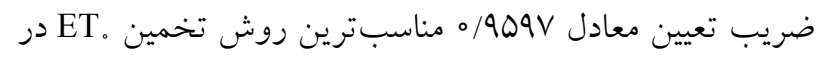

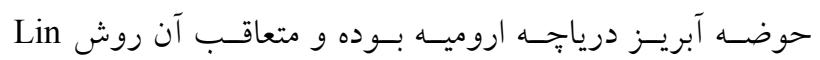

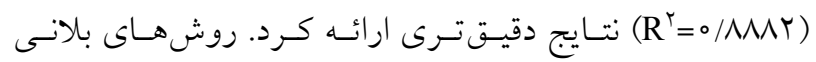

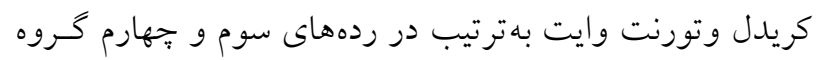

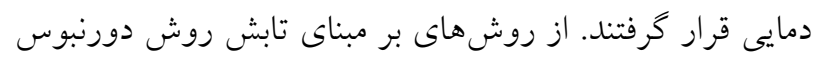

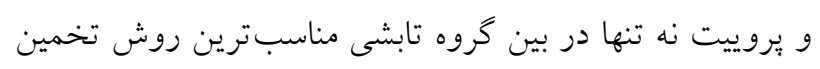
ET。

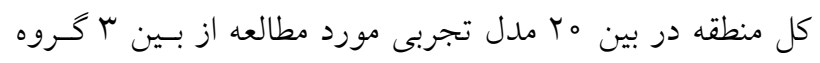

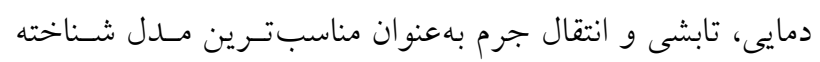

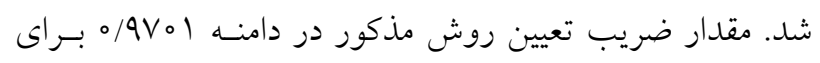

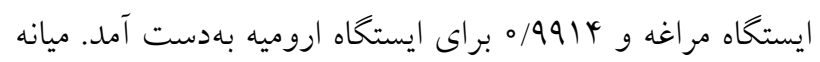

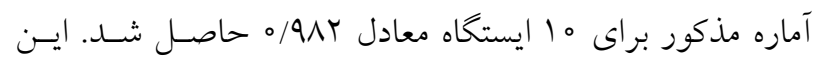

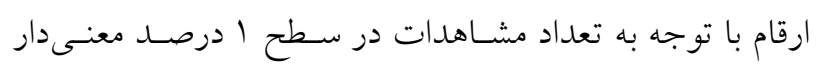

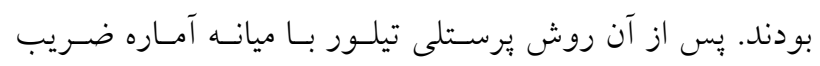

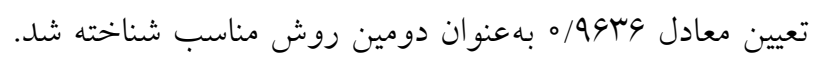

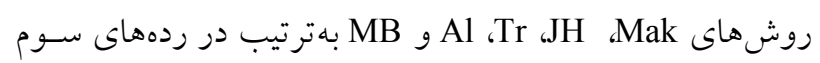

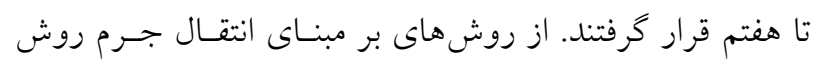

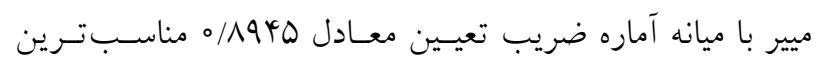

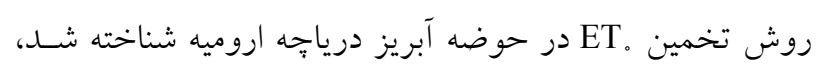

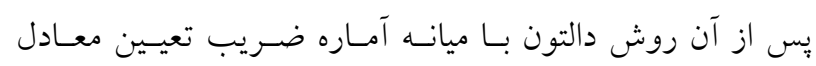

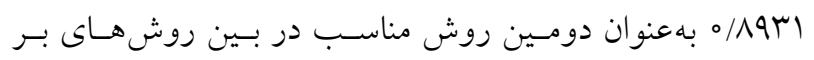

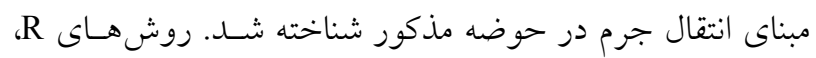

حاضر خواهد بود. بر اين اساس صرفنظر از منطقه مـورد مطالعه

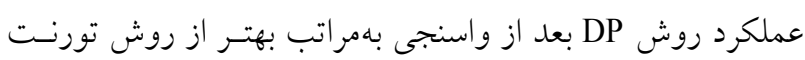

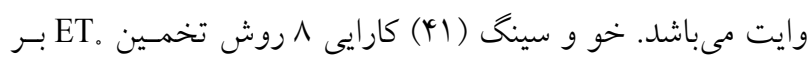

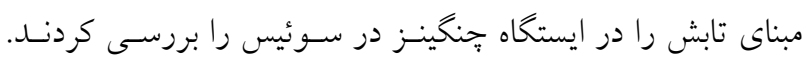

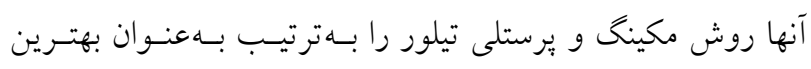

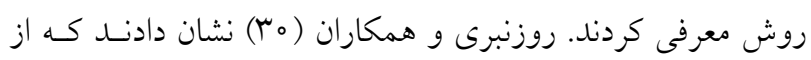

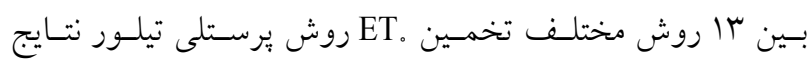

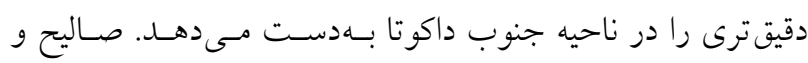

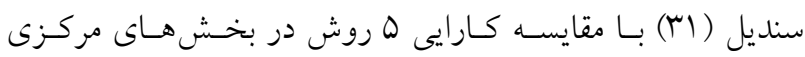

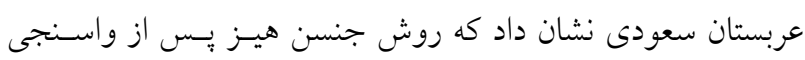

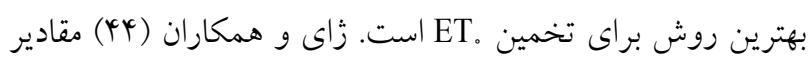

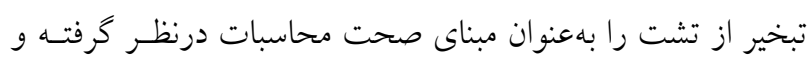

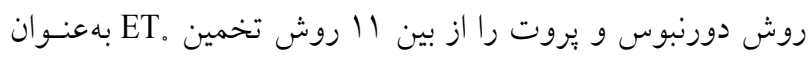

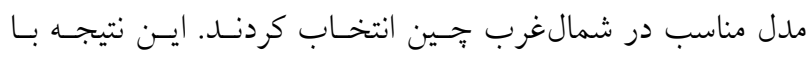

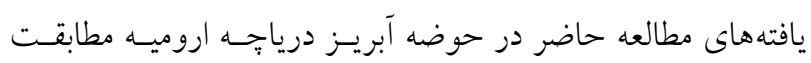

\section{نتيجه كيرى كلى}

براى تخمين دقيق مقدار آب مورد نياز گياهان در حوضه آبريـز

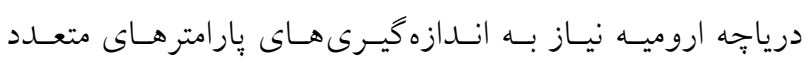

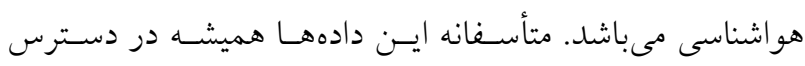

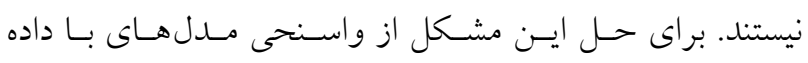

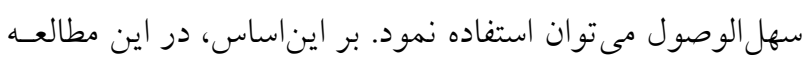

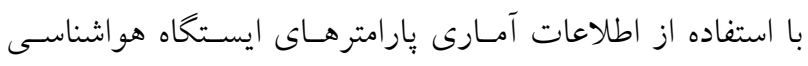

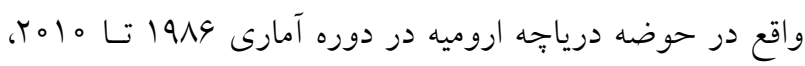

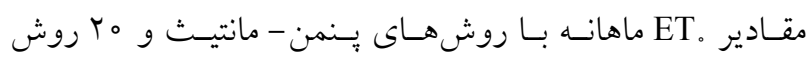

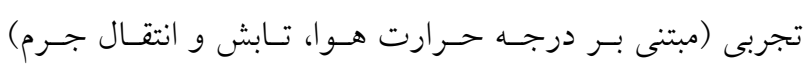

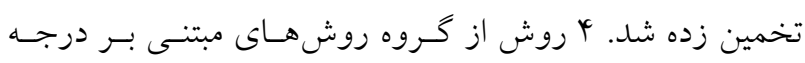
حرارت هوا (هاركريوز، تورنت-وايت، بلانى -كريدل و لاينكر)،

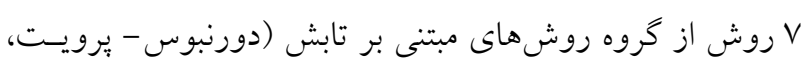

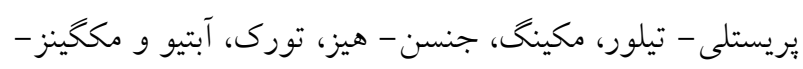

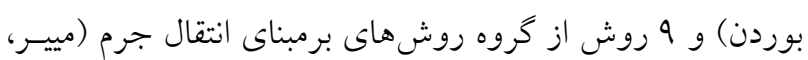




$$
\begin{aligned}
& \text { اروميه است. لازم است جهت مديريت علمى آب كشاورزى در }
\end{aligned}
$$

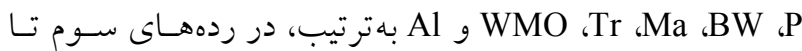

$$
\begin{aligned}
& \text { حوضه درياجِه اروميه مقدار آب مصسرفى گياهـان بـا توجـهـ بــه } \\
& \text { نهم قرار كرفتند. نتايج نشان داد كه استفاده از ضرايب واسـنجى } \\
& \text { نتايج مطالعه فعلى بر آورد و در اختيار گياهان قرار گيرد. افـزون } \\
& \text { براى مدلهاى مورد استفاده كارايى تمام روشها را بهطور قابـل } \\
& \text { بر اين، بهمنظـور افـزايش رانـدمان آبيـارى لازم اسـت نظـارت }
\end{aligned}
$$

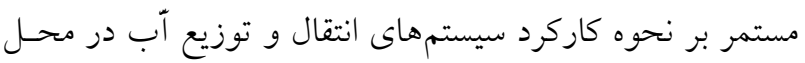

$$
\begin{aligned}
& \text { توزيع يا مصرف صورت گيرد و برنامه عملى بـراى تغييـر نـوع } \\
& \text { سيستمهاى آبيارى سنتى به سيستم آبيارى مدرن توسط تصسميم } \\
& \text { كيران كشاورزى تدوين و اجرا گردد. تا بتوان حدالامكان بخشى } \\
& \text { از بحران آب موجود در منطقه را حل نمود. } \\
& \text { ملاحظهاى افزايش مىدهد. زيرا معيارهاى ارزيـابى بــراى تمـام } \\
& \text { روش ها يس از واسنجى به مقدار قابل توجهى بهبود بيـــا كـرد. } \\
& \text { بهبارت ديخر مقادير آمارههاى MBE RME، و MAE و } \\
& \text { واسنجى كاهش يافت. در حالت كلى مىتوان نتيجه كرفـت كـهـ }
\end{aligned}
$$

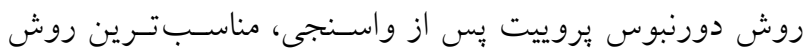

$$
\begin{aligned}
& \text { تخمين مقدار تبخير - تعرق گياه مرجع در حوضه آبريز درياجـهـ }
\end{aligned}
$$

\section{منابع مورد استفاده}

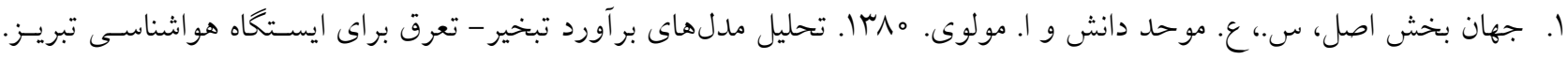

$$
\begin{aligned}
& \text { دانش كشاورزى }
\end{aligned}
$$

r. دهقانى، ا.، م. قبائى سوق، ح. شريفيان و ن. دهقانى. •وبا. واسنجى معادلات تجربى تبخير -تعرق روزانه و مقايسه با شبكه عصبى

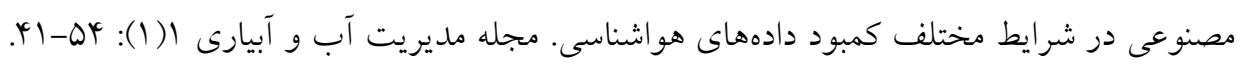

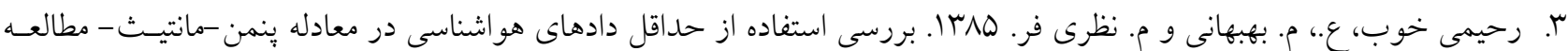

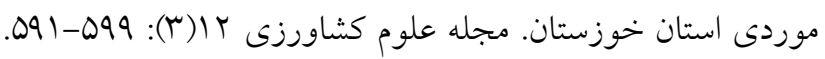

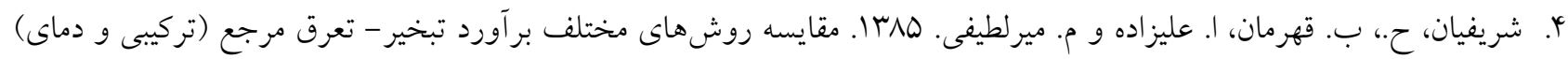

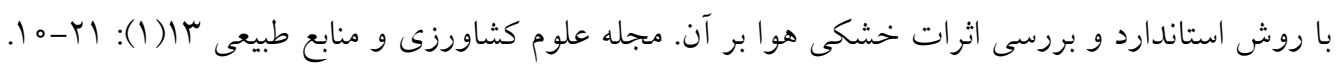

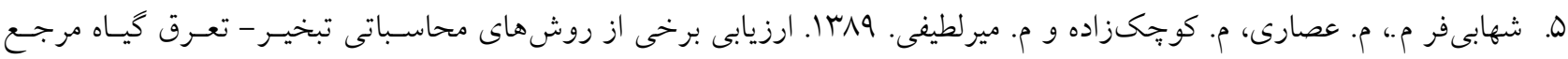

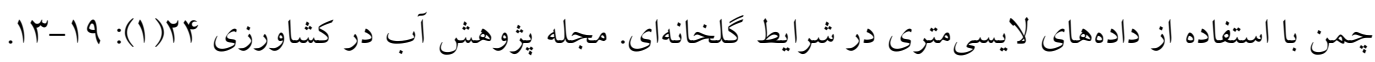

6. Abtew, W. 1996. Evapotranspiration measurement and modeling for three wetland systems in South Florida. Water Resources Bulletin 32: 465-472.

7. Ahmadi, S. H. and Fooladmand, H. R., 2008. Spatially distributed monthly reference evapotranspiration derived from the calibration of Thornthwaite equation: a case study, South of Iran. Irrig. Sci. 26(4): 303-312.

8. Albrecht, F. 1950. Die Methoden zur Bestimmung der Verdunstung der natürlichen Erdoberfläche. Archiv für Meteorologie, Geophysik und Bioklimatologie, Serie B, 2(1-2): 1-38.

9. Allen, R. G., L. S. Pereira, D. Raes and M. Smith. 1998. Crop evapotranspiration-Guidelines for computing crop water requirements-FAO Irrig and Drain paper 56. FAO, Rome, 300(9), p. D05109.

10. Allen, R. G., J. L. Jensen Wright and R. D. Burman. 1989. Operational estimate of evapotranspiration. J. Agro. 81: 650-662.

11. Brockamp, B. and H. Wenner. 1963. Verdunstungsmessungen auf den Steiner See bei Mu“nster. Dt Gewa“sserkundl Mitt 7:149-154.

12. Dai, X., Shi, H., Li, Y., Ouyang, Z. and Z. Huo. 2009. Artificial neural network models for estimating regional reference evapotranspiration based on climate factors. Hydrolo Proc 23: 442-450.

13. Dalton, J. 1802. Experimental essays on the constitution of mixed gases; on the force of steam of vapour from waters and other liquids in different temperatures, both in a Torricellian vacuum and in air on evaporation and on the expansion of gases by heat. Mem Manch Lit Philos Soc. 5: 535-602.

14. DehghaniSanij, H., T. Yamamoto and V. Rasiah. 2004. Assessment of evapotranspiration estimation models for use in semi-arid environments. Agril. Water Manage. 64(2): 91-106. 
15. Doorenbos, J and W.O. Pruitt. 1977. Crop Water Requirements. Irrigation and Drainage Paper 24, Food and Agriculture Organization of the United Nations: Rome, Italy.

16. Gundekar, H. G., U. M Khodke and S. Sarkar. 2008. Evaluation of pan coefficient for reference crop evapotranspiration for semi-arid region. Irrig. Sci. 26: 169-175.

17. Itenfiso, D., R. L. Elliott, R. G. Allen and I. A. Walter. 2003. Comparison of some reference evapotranspiration calculations as part of the ASCE standardization effort. J. Irrig. Drain. Eng. 129(6): 440-448.

18. Jensen, M. E, R. D Burman and R. G. Allen. 1990. Evapotranspiration and Irrigation Water Requirements. American Society of Civil Engineering Manual 70, New York.

19. Jensen, M. E. and H. R. Haise. 1963. Estimating evapotranspiration from solar radiation. Proceedings of the American Society of Civil Engineers, J. Irrig. and Drain Div. 89, pp.15-41.

20. Kochekzade, M. and A. Bahmani. 2004. Evaluating the artificial neural network reducing the need parameters to archive reference evapotranspiration. Agr. Sci. 11: 87-96.

21. Landeras, G., A. Ortiz-Barredo and I. J. Lopez. 2008. Comparison of artificial neural network models and empirical and semi-empirical equations for daily refrence evapotranspiration estimation in the Basque Country (northern Spain). Agr. Water Manage. 95:553-565.

22. Linacre, E. T. 1977. A simple formula for estimating evapotranspiration rate in various climates using temperature data alone. Agr. Mete. 18: 409-424.

23. Mahringer, W. 1970. Verdunstungsstudien am Neusiedler See. Arch. Met. Geoph. Biokl. Ser. B. 18:1-20.

24. Makkink, G. F. 1957. Testing the Penman formula by means of lysimeters. J. Instit. of Water Eng. 11: $277-288$.

25. McGuinness, J. L and E. F. Bordne. 1972. A Comparison of Lysimeter-derived Potential Evapotranspiration with Computed Values. Technical Bulletin 1452, Agricultural Research Service, US Department of Agriculture: Washington, DC.

26. Meyer, A. 1926. U“ ber einige Zusammenhänge zwischen Klima und Boden in Europa. Chem. Erde 2:209-347.

27. Penman, H. C. 1948. Natural evaporation from open water, bare soil and grass. Proc. R. Soc. London(A) 193:120145.

28. Priestley, C. H. B and R. J. Taylor. 1972. On the assessment of the surface heat flux and evaporation using largescale parameters. Monthly Weather Review 100: 81-92.

29. Rohwer, C. 1931. Evaporation from free water surface. USDA Tech Null 217:1-96.

30. Rosenberry, D. O., D. O. Stannard, T. C. Winter and M. L. Martinez. 2004. Comparison of 13 equations for determining evapotranspiration from a praire wetland, cottonwood lake area north Dakota, USA. Wetlands 24(3): 483-497.

31. Salih, A. M. A. and U. Sendil. 1983. Evapotranspiration under extremely arid environment. J. of Irrig. and Drainage Eng. 110(3): 298-303.

32. Sentelhas, P., T. Gillespie and E. A. Santos. 2010. Evaluation of FAO Penman-Monteith and alternative methods for estimating reference evapotranspiration with missing data in southern Ontario, Canada. Agr. Water Manage. 97: 635-644.

33. Singh, V. P. and C. Y. Xu. 1997. Evaluation and generalization of 13 mass-transfer equations for determining free water evaporation. Hydrological Processes 11: 311-323

34. Tabari, H, M. E. Grismer and S. Trajkovic. 2011. Comparative analysis of 31 reference evapotranspiration methods under humid conditions. Irrig. Sci. 31(2): 107-117.

35. Temesgen, B., S. Eching, B. Davidoff and K. Frame. 2005. Comparison of some reference Evapotranspiration equations for California, J. Irrig. Drain Eng. 131(1): 73-84.

36. Thorntwaite, G.W. 1948. An approach toward rational classification of climate. Georg. Rev. 38: 55-94.

37. Trabert, W. 1896. Neue Beobachtungen u“ber Verdampfungsgeschwindigkeiten. Meteorol Z. 13: 261-263.

38. Trajkovic, S. and S. Kolakovic. 2009. Evaluation of reference evapotranspiration equations under humid conditions. Water Resour. Manage. 23: 3057-3067.

39. Turc, L. 1961. Estimation of irrigation water requirements, potential evapotranspiration: a simple climatic formula evolved up to date. J. Annals of Agronomy 12: 13-49.

40. WMO. 1966. Measurement and estimation of evaporation and evapotranspiration. Tech. Pap. (CIMO-Rep) 83. Genf.

41. Xu, C. Y. and V. P. Singh. 2000. Evaluation and generalization of radiation-based methods for calculating evaporation. Hydrological Processes 14: 339-349.

42. Xu, C. Y., V. P. Singh. 2001. Evaluaation and generalization of temperature based methods for calculating evapotration. Hydrological Processes 15: 305-319.

43. Xu, C. Y. and Singh V. P. 2002. Cross comparison of empirical equations for calculating potential evapotranspiration with data from Switzerland. Water Resources Manage. 16: 197-219.

44. Zhai, L., Q. Feng, Q. Li and C. Y. Xu. 2010. Comparison and modification of equations for calculating evapotranspiration (ET) with data from Gansu province, northwest China. Irrig. Drain. 59: 477-490. 


\title{
Comparison and Evaluation of Twenty Methods for Estimating Reference Evapotranspiration Based on Three General Categories: Air Temperature, Solar Radiation and Mass Transfer in the Basin of Lake Urmia
}

\author{
O. Babamiri ${ }^{1 *}$ and Y. Dinpazhoh²
}

(Received: June 22-2014 ; Accepted : April 26-2016)

\begin{abstract}
The aim of this study is to compare and calibrate the 20 empirical methods of estimating evapotranspiration $\left(\mathrm{ET}_{0}\right)$ based on three categories in monthly timescale at the Urmia Lake watershed. For this purpose, the information of 10 synoptic meteorological stations during the period of 1986-2010 was used. Results from the above mentioned methods were compared with the output of the FAO Penman-Monteith (PMF-56) method. Performance of the methods evaluated using the $\mathrm{R}^{2}$, RMSE, MBE and MAE statistics. The best and worst methods of each category were determined for the study area. The best methods of each category were calibrated for the area under study. Results indicated that there is a significant difference between the results of selected methods of each category and the PMF-56 method. Performance of the selected methods remarkably increased after calibration. Among the temperature-based group, the HG method having the median $\mathrm{R}^{2}$ value of 0.9597 was recognized as the best method. Among the radiation-based group, the DP model was selected as the best method in the study area. Furthermore, the median of $\mathrm{R}^{2}$ values was 0.982 . Finally, among the mass transfer-based group, having $\mathrm{R}^{2}=0.8945$, the Meyer method was selected as the best method of this group for the study area. From mass transfer based group, the D method was found as the second best method in the study area. Temperature based methods and mass transfer based methods were ranked second and third, respectively. In general, it can be concluded that after calibration the DP method is suitable to estimate reference crop evapotranspiration among 20 selected methods in the Urmia Lake basin.
\end{abstract}

Keywords: Evapotranspiration, Mass transfer, Penman- Monteith, Radiation, Temperature, Urmia Lake

1. Dept. of Water Eng., Faculty of Agric. Bu Ali Sina Univ., Hamadan, Iran.

2. Dept. of Water Eng., Faculty of Agric. Tabriz Univ., Tabriz, Iran.

*: Corresponding Author, Email: obabamiri@yahoo.com 